\title{
INTERAÇÃO MICROBIOLOGIA - FUNGICIDAS NO TRATAMENTO DE SEMENTES DE ALFAFA VISANDO REDUÇÃO NA TAXA DE SEMEADURA
}

\author{
PATRICIA PERONDI ANCHÃO \\ Engenheira Agrônoma
}

Orientador: Prof. Dr. Moacyr Corsi

Dissertação apresentada à Escola Superior de Agricultura "Luiz de Queiroz", da Universidade de São Paulo, para obtenção do Título de Mestre em Agronomia , Área de Concentração: Ciência Animal e Pastagens.

P I R A C I C A B A

Estado de São Paulo - Brasil

Abril - 1995 
CATALOGACAO NA PUELICACAO

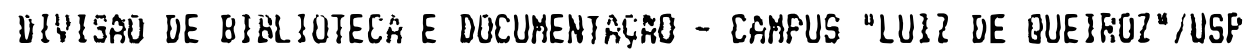

Anchiso, Patricia Perondi

A539i Interaço aicrobioloqia-fungicidas no tratamento de semente de alfafa visando a reduça na taka de semeadura. Piracicabá, 1995.

8A, ilus.

Diss. (Mestre) - ESALQ

gibliografia.

1. Altata - Semente - Doenca 2. Alfata - Seberite - Iratamento 3. Fungicida e semente 1. Escola Superior de Agricultura Luiz de Queiroz, firacicaba 


\section{INTERAÇÃO MICROBIOLOGIA-FUNGICIDAS NO TRATAMENTO DE SEMENTE DE ALFAFA VISANDO REDUÇÃO NA TAXA DE SEMEADURA}

\section{PATRÍCIA PERONDI ANCHÃO}

Aprovada em 19/04/1995

Comissão Julgadora:

Prof . Doutor Moacyr Corsi ESALQ/USP

Prof. Doutor Iroshi Kimati ESALQ/USP

Profa. Doutora Siu Mui Tsai CENA/USP

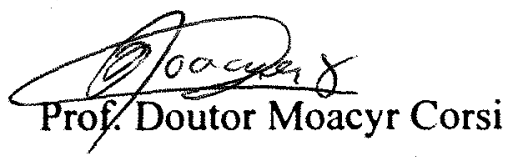

Orientador 
Aos meus pais, irmãos e amigos,

Ofereço.

Dedico:

À minha avó Amélia, que deixou sua filha para me apoiar como ela faria se ainda vivesse, e ao Prof. Moacyr Corsi, pela atenção sempre presente. 


\section{AGRADECIMENTOS}

A DEUS, na presença do meu anjo da guarda, pela proteção e força oferecida.

Ao Departamento de Zootecnia de Ruminantes e ao CPZ.

Ao Departamento de Fitopatologia, em especial ao Prof. Iroshi e à Izabel.

Ao Seção de Microbiologia do CENA, em especial à Dra. Tsai e ao Francisco.

À Prefeitura do Campus, em especial ao Sr. Hermínio.

À CAPES, pela Bolsa de Estudos.

À FAPESP, por financiar este trabalho.

À Maria Del Pilar Diaz, pela paciência durante as análises estatísticas.

A todos aqueles que dispensaram sua atenção contribuindo para finalização deste trabalho. 


\section{SUMÁRIO}

Resumo $\quad$ i

Summary

1. INTRODUÇÃO

2. REVISÃO BIBLIOGRÁFICA 3

2.1. Patógenos possíveis causadores de damping-off em alfafa. 3

2.1.1. Características do gênero Phytophthora 3

2.1.2. Caracteristicas do gênero Pythium 4

$\begin{array}{ll}\text { 2.1.3. Caracteristicas do gênero Rhizoctonia } & 7\end{array}$

$\begin{array}{ll}\text { 2.1.4. Características do gênero Fusarium } & 8\end{array}$

2.2. Técnicas de isolamento e inoculação dos patógenos 9

2.3. Tratamento de sementes com fungicidas e seu efeito sobre a

$\begin{array}{lr}\text { rizobiologia } & 12\end{array}$

2.4. Taxas de semeadura, stand e uso de fungicidas para o tratamento

$\begin{array}{lr}\text { de sementes } & 18\end{array}$

3. MATERIAL E MÉTODOS 24

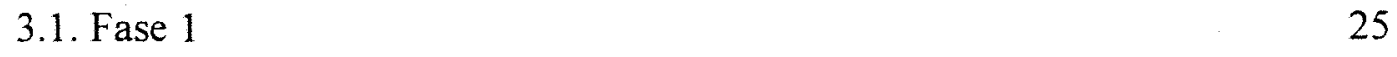

$\begin{array}{lr}3.2 . \text { Fase } 2 & 28\end{array}$ 
3.2.1. Inoculação e tratamento de sementes com Rhizobium meliloti para experimento em vasos com solo

3.2.2. Preparo do solo utilizado 30

3.2.3. Plantio e irrigação 30

3.2.4. Parâmetros mensurados do experimento em vasos com solo 31

3.2.5. Inoculação e tratamento de sementes com fungicidas para os vasos de Leonard $\quad 32$

3.2.6. Preparo dos vasos de Leonard 33

3.2.7. Plantio nos vasos de Leonard 34

3.2.8. Parâmetros mensurados do experimento com vasos de Leonard 34

3.3. Fase $3 \quad 35$

3.3.1. Unidades experimentais 35

3.3.2. Inoculação de patógenos 36

$\begin{array}{lll}\text { 3.3.3. Plantio } & 37\end{array}$

$\begin{array}{lll}\text { 3.3.4. Irrigação } & 37\end{array}$

3.3.5. Controle das ervas daninhas $\quad 37$

3.3.6. Parâmetros mensurados 37 
4.1. Fase 1 - Coleta do material em campos de alfafa, com sintomasde

damping-off, posterior preparo do inóculos e teste de patogenicidade

4.2. Fase 2 - Experimentos em casa-de-regetação para avaliar os efeitos dos fungicidas sobre as taxas de emergência, sobrevivência, produção das plantas e sobre a rizobiologia destas

4.3. Fase 3 - Experimento a campo com o objetivo de estudar várias taxas de semeadura e os efeitos do tratamento de sementes com fungicidas

5. CONCLUSÕES 


\section{INTERAÇÃO MICROBIOLOGIA - FUNGICIDAS NO TRATAMENTO DE SEMENTE DE ALFAFA VISANDO A REDUÇÃO NA TAXA DE SEMEADURA}

Autora: Patrícia Perondi Anchão

Orientador: Moacyr Corsi

\section{RESUMO}

Existe uma grande variação na recomendação de taxas de semeadura para plantio de alfafa, que é influenciada pelo aparecimento de damping-off nas plântulas.

Este trabalho teve por objetivo isolar os fungos possiveis causadores de damping-off na cultura de alfafa no Estado de São Paulo, avaliar o uso de fungicidas sobre as taxas de emergência, sobrevivência, produção e rizobiologia das plantas e testar várias taxas de semeadura a campo associada com o uso de fungicidas.

Os fungos isolados foram a Rhizoctonia solani e o Fusarium sp., sendo os efeitos da Rhizoctonia mais drásticos. Os gêneros dos fungos encontrados estão ligados a época do ano da coleta, local e ambiente (temperatura e umidade).

$\mathrm{O}$ uso de fungicidas no tratamento de sementes apresentou um efeito positivo, em casa-de-vegetação, no início da cultura, que se diluiu com o passar do 
tempo. Em condições de campo na presença simultânea dos dois patógenos o fungicida não apresentou efeito.

Houve um resultado interativo entre a estirpe de Rhizobium meliloti utilizada e o fungicida empregado quer no tratamento de semente como em superfície. Não se recomenda a associação da estirpe de Rhizobium SEMIA 135 com tratamento de semente e solo com Iprodione.

$\mathrm{O}$ aumento na taxa de semeadura acima de $10 \mathrm{Kg}$ não promoveu aumento no stand e consequentemente na produção de matéria-seca na presença dos dois patógenos em condições de campo. 
MICROBIOLOGY-FUNGICIDE INTERACTION ON THE TREATMENT OF ALFALFA SEEDS AIMING AT A REDUCTION ON SEED RATE

Author: Patrícia Perondi Anchão Adviser: Moacyr Corsi

\section{SUMMARY}

There is a wide range of seed rates recommended for the establishment of an alfalfa field, wich is influenced by the damping-off disease.

The objectives of this study were to isolate possible microorganisms causing damping-off of alfalfa seedlings in the State of São Paulo; evaluate fungicidde use upon emergence rates survival, production and rhizobiology of plants and test several seed rates in association with fungicide applications in a field condition.

The fungi isolated were Rhizoctonia solani and Fusarium sp. Rhizoctonia was the most important pathogen causing damping-off in the alfalfa fields in São Paulo. The pathogens collected in the field may be influenced by environment conditions. High temperatures and humidity during the field collectons may have favoured Fusarium and Rhizoctonia and not other damping-off pathogens. This fact suggest that research on fungicides to control damping-off disease may have to consider environment asn an important factor to study. 
The use of fungicides on seed treatment showed a positive effect under glasshouse conditions during the early stages of the crop but was not persistent over time. On field condition, under simultaneous presence of both $R$. Solani and Fusarium sp, the fungicide treatment did not present any measurable effect.

There were significative interactions between the strain of Rhizobium meliloti and the fungicide used in both the seed and soil treatment. The SEMIA 135 strain is not recommended un association with soil and seed treatment based on Iprodione.

Under field conditions, seed rates higher than $10 \mathrm{Kg} /$ ha did not result in any increase on population of plants (stand) and dry matter yield when both $R$. solani and Fusarium $s p$ were present. 


\section{INTRODUÇÃO}

Uma das práticas agrícolas que vem se tomando frequente é o uso de tratamento de sementes com fungicidas e inseticidas para sementes pequenas, como é o caso da cultura de alfafa.

Esse tratamento de sementes tem por objetivo uma redução na quantidade de semente utilizada por unidade de área, visto que, com o uso de fungicidas haveria um controle sobre as doenças de sementes e seedlings que causam "damping-off" (morte de plântulas) na alfafa. Existem atualmente, recomendações diversas em relação a quantidade de semente que deve ser utilizada no plantio e, também quanto ao stand necessário para o sucesso no estabelecimento da cultura. Como o custo dessa semente é bastante alto, U\$ 10.00 a U $\$ 15.00$ por quilo, e as recomendações para a densidade de semeadura variam de 5 a $50 \mathrm{Kg}$ de semente/ha, torna-se relevante definir com muita precisão, a densidade de semeadura quando se pretende estabelecer grandes áreas de alfafa.

Atualmente, há recomendações para uso de fungicidas no Brasil, mas pouco se conhece sobre os patógenos causadores de damping-off em alfafa. Desconhece-se, 
também, as consequências do uso desses fungicidas sobre a implantação dessa cultura, tanto em relação as mudanças nas recomendaçôes tradicionais de semeadura, como também, as influências do uso de fungicidas associados à inoculação com Rhizobium meliloti (bactéria simbiótica, fixadora de $\mathrm{N}_{2}$ ) que pode ser depressivo, não influenciar ou incrementar os fatores produtivos, tais como podução de nódulos e biomassa das plantas.

O trabalho proposto por este projeto consistiu, inicialmente, na coleta, no isolamento e na identificação dos patógenos causadores de damping-off em sementes e plântulas de alfafa. Em casa-de-vegetação pretendeu-se testar o uso de tratamento de sementes com dois fungicidas ( Iprodione e Thiram), na presença dos patógenos isolados, combinados com o uso de inoculação com o Rhizobium meliloti . Sob condições de campo foram estudadas as taxas de semeadura, seus respectivos stands e as influências sobre os fatores de produção da alfafa irrigada. 


\section{REVISÃO BIBLIOGRÁFICA}

\subsection{Patógenos de damping-off em alfafa.}

Os fungos consistem o grupo de microorganismo que mais atacam a alfafa (HONDA \& HONDA, 1990).

Existem alguns patógenos, Phytophthora, Pythium, Aphanomyces, Fusarium. Rhizoctonia e Rhizopus que são conhecidos por causarem doenças nas sementes e plântulas, o que concorre para haver redução no stand inicial de plantas na cultura da alfafa (GRAU, 1990, ERWIN, 1990 e HONDA \& HONDA, 1990).

\subsubsection{Características do gênero Phytophthora.}

A ocorrência do fungo Phytophthora está associada a condições que favoreçam a presença de água livre no solo, quer seja por drenagem impedida ou por irrigação por inundação. Essa doença pode ser particularmente devastadora em stands recém estabelecidos, podendo causar damping-off das plântulas. (ERWIN, 1990). A temperatura ótima para infecção está entre 24 e $27^{\circ} \mathrm{C}$, sendo desfavoráveis temperaturas mais altas. A principal espécie que causa doenças em alfafa é a Phytophtora megasperma

Drechs f. sp. medicaginis. 
Esse fungo ao infectar as sementes e plântulas provoca sintomas similares àqueles que ocorrem quando a cultura é atacada pelo Pythium, o conteúdo da semente torna-se uma massa gelatinosa marrom, ou a radicula e os cotiledones podem tornar-se marrons e flexiveis após a emergência. Quando a infecção ocorrer em estágios mais avançados atacará o hipocótilo e a raíz, tornando as plântulas umedecidas e flácidas, provocando colapso e murcha. (GRAU, 1990).

A Phytophthora pode causar infecções no início do crescimento e na emergência das raízes laterais. Os nódulos das raízes, formados pelo Rhizobium meliloti, também podem ser atingidos. Esse fungo que também ataca as raizes da planta adulta é relativamente especifico para essa cultura. (HANSON, 1988).

Como medidas de controle eficientes estão o manejo da água de irrigação, evitando-se, inclusive, solos com drenagem impedida. $\mathrm{O}$ uso de cultivares resistentes pode não ser expresso quando as plântulas estão em início do estabelecimento, para prevenção do damping-off o uso de um tratamento de sementes sistêmico, com fungicida como o metalaxyl tem sido indicado (ERWIN, 1990). RHODES \& MYRES (1989) testaram os fungicidas metalaxyl e pyroxyfur e concluíram que o metalaxyl foi o mais eficiente.

\subsubsection{Características do gênero Pythium.}

Os fungos do gênero Pythium são conhecidos por causarem damping-off na cultura da alfafa, persistindo sobre os resíduos vegetais na forma de oosporos ou como 
esporângios. (GRAU, 1990). As espécies do gênero Pythium mais frequentemente isoladas de alfalfa são o $P$. ultimun Trown, $P$. irregulare Buisman e $P$. splendens $\mathrm{H}$. Braun. No Estado da Califórnia no EUA existem áreas que apresentam problemas de emergência das plântulas, chegando a aparecer porcentagens de emergência da ordem de 30 a $65 \%$ apenas, esse fato foi atribuido a ocorrência de três gêneros de fungos principalmente Pythium, Rhizoctonia e Fusarium. (HANCOCK, 1983).

Existem condições ambientais que favorecem $\mathrm{o}$ ataque do Pythium e desfavorece a germinação das sementes, isso ocorre quando existe alta umidade do solo e baixas temperaturas. A temperatura ótima para o damping-off é $16^{\circ} \mathrm{C}$. quando ocorre em pré-emergência, e entre 24 e $28^{\circ} \mathrm{C}$, quando ocorre em pós-emergência (GRAU, 1990).

Os sintomas das plantas e sementes atacadas por Pythium anteriormente caracterizam-se pelo fato do conteúdo da semente tornar-se marrom e gelatinoso, pela radícula e hipocótilo da plântula ficarem marrons e flexíveis após a emergência. Quando a infecção é mais tardia as plântulas apresentam o hipocótilo e a raiz flácidos e gelatinosos, crescimento retardado, sofrendo finalmente o damping-off. Caso as condições ambientais sejam favoráveis a plântula poderá sobreviver através da ramificação da raiz. Em condições de campo parece que as plântulas tornam-se resistentes ao damping-off após 5 dias de emergência, mas ainda existe risco de ocorrer a infecção pela doença (GRAU, 1990). 
HANCOCK (1983) associou a presença de raizes bifurcadas à presença do fungo Pythium. Essas raizes são formadas a partir das lesões sobre as radículas das plântulas, aparecendo na alfafa em número variável de uma até seis ramificações. As plantas com esse tipo de raiz perduram em stands estabelecidos, apresentando com o passar do tempo um decréscimo em sua população. São plantas que possuem o crescimento comprometido, podendo ter o peso da parte-aérea reduzido em até $45 \%$.

Como medidas de controle tanto para Pythium como para Phytophthora, o uso de maiores taxas de semeadura (que compensam parcialmente as perdas a campo) e do fungicida metalaxyl em tratamento de sementes são fatores que favorecem o rápido crescimento da raiz e concorrem para amenizar os efeitos do ataque desses fungos. (GRAU, 1990). O uso do fungicida ethazole aplicado ao solo mostrou resultado efetivo no controle ao Pythium, sendo que o uso de PCNB, ethazole ou thiabendazole teve uma grande influência em diminuir o grau de incidência de raízes bifurcadas nas plântulas (HANCOCK, 1983).

Na Nova Zelândia HAWTHORNE (1987), estudando fatores associados com a pobre emergência e crescimeto de alfafa, em 22 tipos diferentes de solo, encontrou o Pythium causando damping-off de pós emergência inutilizando entre 5 e $15 \%$ das sementes viáveis. 


\subsubsection{Caractésticas do gênero Rhizoctonia.}

Esse fungo pode atacar as plântulas de alfafa e sementes provocando o damping-off de pré e pós emergência. (ERWIN, 1990). O aparecimento de damping-off de pós-emergência é muito mais comum ao ataque desse fungo. (ERWIN, 1990 e HANCOCK, 1983). Sob condições de alta umidade e temperatura, quando o aparecimento dessa doença é favorecido, as perdas de plântulas e sementes são muito maiores. A temperatura ótima de crescimento está entre 25 e $30^{\circ} \mathrm{C}$ cessando aos $35^{\circ} \mathrm{C}$. (ERWIN, 1990).

O fungo Rhizoctonia sobrevive no solo ou em material vegetativo morto não necessitando de hospedeiro, pois vive saprofiticamente. (ERWIN, 1990). RUSH e WINTER, (1990) estudando a influência das culturas prévias sobre o ataque desse fungo na cultura da beterraba encontrou que as maiores perdas do stand da beterraba $(47 \%)$ devido a podridão de raízes ocorreu quando esta cultura foi precedida pela cultura da alfafa.

$\mathrm{O}$ ataque do fungo ocorre nos vários estágios de crescimento tornando as raizes e partes inferiores encurvadas e marrons e provocando damping-off. (ERWIN, 1990).

Não se conhecem medidas efetivas de controle contra Rhizoctonia em alfalfa, apesar de alguns cultivares de alfafa selecionadas parecerem mais tolerantes devido ao vigor na emissão de raízes. (ERWIN, 1990). 
HANCOCK (1983) conseguiu bom controle apenas com tratamento de solo com o fungicida PCNB, quando a concentraçào de inóculo de Rhizoctonia no solo foi alta.

No Compêndio de Defensivos Agricolas (1990) o fungicida Iprodione é indicado para o controle de Rhizoctonia solani no tratamento de semente do algodão. MARINGONI (1991) obteve os melhores resultados no tratamento de semente de feijão quando utilizou o iprodione $(1,0 \mathrm{~g}$ i.a. $/ \mathrm{Kg}$ de semente) ou iprodione + thiram ( $0,5 \mathrm{~g}$ i.a. $+1,5 \mathrm{~g}$ i.a./Kg de semente) no controle do tombamento de plantas em condições de vasos.

HANCOCK (1993) utilizou os fungicidas metalaxyl e benomyl em área total anualmente para controle do Pythium, Fusarium e Rhizoctonia durante três anos. Os fungicidas não promoveram efeito sobre a queda do stand e apenas o benomyl aumentou a produção do cultivar WL 516 no terceiro ano de colheita.

\subsubsection{Características do gênero Fusarium.}

O gênero Fusarium é também conhecido como causador de dampig-off em plântulas de alfafa conforme ocorre nos Estados Unidos. (ERWIN, 1990 e HANCOCK, 1983). Esse fungo também foi citado provocando damping-off, causando apodrecimento do sistema radicular ou tombamento das plântulas no Brasil. (HONDA \& HONDA, 1990). Esse fungo sobrevive no solo como clamidosporos, no tecido vivo e em plantas mortas como micélios, podendo o solo permanecer infestado por vários anos. O fungo é 
favorecido por altas temperaturas, sendo a ótima em torno de $25^{\circ} \mathrm{C}$, o aumento da umidade do solo não tem relação com a incidência da doença. (ERWIN, 1990).

$\mathrm{O}$ fungo infecta pequenas raízes ou penetra através de ferimentos da raiz pivotante e progride através do sistema vascular das plantas. há descoloração do tecido hospedeiro, e, conforme avançam as hifas, eliminando as toxinas, há entupimento do sistema vascular e as plantas secam. Pode haver morte das plantas dentro de cinco dias, quando estas são infectadas com uma suspensão contendo conídeos. As folhas das plantas atacadas podem tornar-se avermelhadas. (ERWIN, 1990).

Esse fungo é resistente no solo por vários anos, sendo recomendado como prática de controle o uso de cultivares resistentes. (ERWIN, 1990 ). HANCOCK, (1983) usou thiabendazole no tratamento de solo, um fungicida ativo contra a fusariose, entretanto, não obteve resultados quando avaliou diferentes intensidades do inóculo aplicados ao solo.

\subsection{Técnicas de isolamento e inoculação dos patógenos.}

Algumas técnicas para isolamento dos possíveis patógenos causadores de damping-off em plântulas ou doenças em sementes de alfafa foram revistas, uma vez que esse assunto é pouco explorado em nosso meio.

MARKS \& MITCHELL (1970) estudando a detecçâo, isolamento e potogenicidade da Phytophthora megasperma de solos e a estimativa do nível de inóculo existente no solo usaram a seguinte técnica: sementes de alfafa foram desinfetadas em 
$3 \%$ de hipoclorito de sódio, por 30 segundos, depois lavadas em água esterilizada e colocadas para germinar em Placas de Petri com papel de filtro úmido. A germinação ocorreu entre 24 a 36 horas em temperatura de 22 a $24^{\circ} \mathrm{C}$, sendo que as plântulas foram preparadas para o uso 72 horas após quando as radículas estavam com 6 a $10 \mathrm{~mm}$ de comprimento e a testa da semente rompidas com o aparecimento dos cotilédones. Foram usados $30 \mathrm{cc}$ de solo colocados em placas de Petri cobertos com 2 a $3 \mathrm{~mm}$ de água destilada (35 a $40 \mathrm{ml}$ ), onde seis daquelas plântulas foram flutuadas em cada placa sendo que previamente o hipocólito e os tecidos radiculares foram esmagados em dois ou três pontos com uma tesoura para retardar a maturação das plântulas. Durante todo o tempo as plântulas ficaram submersas e as placas foram incubadas a $20-22^{\circ} \mathrm{C}$ por seis dias.

O fungo foi isolado de pequenos pedaços desses cotílendones frescos infestados. Esse material foi mantido em água-ágar com adição de antibióticos e colocados em placas incubadas entre 20 e $22^{\circ} \mathrm{C}$ e observados 16 a 24 horas após. Nesse estágio foi possível identificar e fazer isolados de hifas, que serviram para inocular os solos.

Para o isolamento desses fungos, Pythium, por exemplo, pode-se usar o método descrito por TSAO (1970), onde o solo infestado foi colocado em um backer e seu volume completado com água, sendo incubado a temperatura de 20 a $25^{\circ} \mathrm{C}$. Depois de 24 horas foram colocados pedaços de brotos de alfafa na superficie para que esses fossem infectados e pudessem ser isolados. Após o isolamento o patógeno foi multiplicado em grãos de trigo que foram lavados em água corrente por duas horas, 
depois acondicionados e autoclavados a $120^{\circ} \mathrm{C}$ durante 40 minutos por dois dias consecutivos. Após esses tratamentos os grãos de trigo foram reumidecidos com $100 \mathrm{ml}$ de água esterilizada em câmara de fluxo laminar. Colônias crescidas por 7 dias em meio água-batata-dextrose (BDA), contidas em placa de Petri foram trasnferidas (discos de $5 \mathrm{~mm}$ de diâmetro) para os grãos autoclavados. Esses recipientes foram agitados e incubados em câmara de crescimento vegetal a $23 \pm 2^{\circ} \mathrm{C}$ sob regime alternado de 12 horas de luz fluorescente e 12 horas de escuro, durante 10 dias. Após o tratamento esse material é utilizado como inóculo.

HANCOCK (1983) usou como técnica de isolamento geral de patógenos que atacam as plântulas de alfafa uma dissecação microscópica para avaliar o crescimento de hifas no material vegetativo. Depois tecidos de raizes e hastes com lesões foram colocadas em placas de Petri com $1,5 \%$ ágar e incubadas à temperatura de $22^{\circ} \mathrm{C}$.

Em alguns testes uma imersão do tecido infectado em solução com $1 \%$ de hipoclorito de sódio durante 30 segundos precedeu a suspensão em água estéril por 5 minutos dos tecidos infectados. Isolados dos fungos foram mantidos em BDA até a identificação.

RHODES \& MYRES (1989) testando o efeito do tratamento de sementes de alfafa para controle do damping-off causado pela Phytophtora megasperma usaram como metodologia de inoculação do solo culturas de $P$. megasperma em ágar misturada ao solo. O solo a ser infestado foi peneirado até obtenção de grânulos menores que $5 \mathrm{~mm}$ de diâmetro e autoclavado a $121^{\circ} \mathrm{C}$ por 1 hora. Depois incorporaram a esse solo cultura 
de $P$. megasperma, onde dois isolados do fungo cresceram em BDA por 5 dias a $21^{\circ} \mathrm{C}$, quando as colônias possuiam aproximadamente $4 \mathrm{~cm}$ de diâmetro. Dessas placas foram retiradas 8 pedaços circulares de $4 \mathrm{~cm}$ de diâmetro e $5 \mathrm{~mm}$ de altura e misturadas em 100 $\mathrm{ml}$ de água por 3 segundos para cada isolado. Depois essa solução foi diluída em $400 \mathrm{ml}$ de água e misturada a 12 litros de solo a ser infestado, que foi transferido posteriormente para os recipientes que seriam usados como parcelas experimentais.

ERWIN (1990) relata que pode-se isolar o fungo Phytophthora através de pequenos pedaços de plântulas lavadas, recentemente infectadas, que são transferidos para ágar-água ou para uma diluição de suco V8 e água (1:10) ou ainda sobre um meio seletivo. A frequência de isolamento é muito baixa (de 1 a 10\%), mas aumenta quando se utiliza o meio seletivo. Após o isolamento há necessidade de realização dos testes de isolamento e patogenicidade.

GRAU (1990) diz que é possível o isolamento do Pythium através de pedaços de plantas bem lavadas transferidas para meio ágar-água, onde o crescimento se dará em dois dias.

\subsection{Tratamento de sementes com fungicidas e seu efeito sobre a rizobiologia.}

Os fungicidas têm uso limitado no tratamento de sementes de alfafa, provavelmente devido ao fato dos primeiros trabalhos sobre controle de doenças não terem demonstrado efeitos benéficos (TYLER, 1956). Entretanto, naqueles trabalhos executados a campo, não se determinou a presença dos patógenos a fim de que o 
fungicida pudesse definir seu efeito sobre a composição do stand estabelecido. Por outro lado, um dos efeitos benéficos do uso de fungicidas seria reduzir a taxa de semeadura como componente para baixar o custo de formação de um alfafal. Neste caso, sem o controle de taxa de semeadura, preparo do solo e qualidade de semente, não se poderia ter idéia correta do efeito do tratamento com fungicida.

Dados mais recentes avaliam os fungicidas como fator preponderante no aumento do estabelecimento do stand sob condições experimentais (Fallon \& Skipp, 1982 citados por HANSON, 1988), havendo recomendações do uso de metalaxyl no tratamento de sementes contra os prejuizos causados por Pythium e Phytophthora.

Altas taxas de semeadura compensam parcialmente o baixo stand a campo. Proteção com fungicidas (como metalaxyl) são efetivos em casa-de-vegetação e no campo para controle de Pythium e Phytophthora no complexo de doenças de plântulas (GRAU, 1990). HANCOCK (1983) usou o PCNB, ethazole e thiabendazole para o controle de Pythium e PCNB para Rhizoctonia encontrando resultados favoráveis no estabelecimento da alfafa.

Existem também recomendações do uso do fungicida Thiram para o tratamento de sementes de alfafa no Brasil (KEPLIN e SANTOS, 1991).

Existe um efeito biológico do tratamento de sementes de leguminosas que dependerá da dose de fungicida aplicada, da estirpe de Rhizobium utilizada na inoculação, do solo, de fatores climáticos, e de outros microrganismos existentes na microbiota da rizosfera. Esse efeito pode ser depressivo, não influenciar ou incrementar 
os fatores produtivos de uma cultura (ISOI \& YOSHIDA, 1988; CORING \& LASKOWKI, 1982 citados por RENNIE et alli, 1985). Sabendo-se dos efeitos biológicos causados pelo tratamento de sementes de leguminosas sobre, principalmente a rizobiologia do sistema, procurou-se recuros na literatura sobre o uso de fungicidas em outras leguminosas, uma vez que essa informação é pouco disponivel para alfafa.

O fungicida Thiram foi o menos tóxico (entre PCNB, Captan e Carboxim) para B. japonicum em soja, e o mais tóxico para dois cultivares de ervilha e amendoim. Para o amendoim foram testadas cinco estirpes comerciais de Rhizobium combinadas com esses fungicidas e concluiu-se que as recomendações para o tratamento de sementes devem considerar as interações entre o fungicida e a estirpe Rhizobium, devido à variabilidade na nodulação (BACKMAN, 1978).

Estudando Rhizobium leguminosarum específicos para a ervilha, lentilha e feijão fava e os fungicidas Thiram e Metalxyl (entre outros), RENNIE (1985) não encontrou efeitos sobre a emergência para lentilha e feijão fava, enquanto que para a ervilha todos os fungicidas melhoraram a porcentagem de emergência. Neste trabalho o autor mediu produção de matéria-seca, número de nódulos e atividade de redução de acetileno (ARA). Thiram e Metalxyl estimularam o ARA para as três leguminosas no primeiro ano. Metalaxyl diminuiu o ARA para o feijão fava no segundo ano. $O$ autor concluiu que o fungicida Thiram foi o mais recomendado para o tratamento de semente de ervilha e lentilha. 
GUPTA et alli (1988), trabalhando com soja e Bradyrhizobium japonicum e vários fungicidas constataram que: a) o efeito do pós tratamento (inoculação antes do tratamento com fungicida) é menos prejudicial para a população do Rhizobium nas sementes; b) dos fungicidas testados Thiram é o menos prejudicial para essa população. assim como para a do solo; c) o fungicida Thiram também provocou a diminuição da população fúngica do solo, favorecendo os aumentos da população bacteriana, e consequentemente a nodulação e produção de grãos.

Além disso, os autores acreditam haver sinergismo entre Thiram e as estirpes de Rhizobium testadas, pois o mesmo, em pré-tratamento, provocou aumento significativo da nodulação.

O fungicida Thiram aplicado em soja e feijão (comum) usando a técnica boxroot (raízes crescendo em vasos que propiciam o acompanhamento do seu desenvolvimento), foi pesquisado por YOSHIDA \& ISOI (1988), que concluíram que o R. leguminosarum bv. phaseoli (estirpe n. 606) utilizado na inoculação do feijão foi pouco afetada pela aplicação de Thiram, observando-se que o número de nódulos e o peso da matéria fresca desses aumentaram com a aplicação de fungicida. Por outro lado Bradyrhizobium japonicum (estirpe n. 001) teve seu crescimento inibido em meiolíquido com Thiram sendo a nodulação da soja diminuída nos box-root até $6 \mathrm{~cm}$ de profundidade com o tratamento.

MONTEIRO et alli (1990) pesquisaram a sobrevivências de Rhizobium leguminosarum bv. phaseoli (estirpe CM 01 e CM 34) em sementes tratadas com 
fungicidas e encontraram que a sobrevivência foi afetada por Thiram após 24 horas a níveis que impedem o uso dessa tecnologia. Houve, também, influência na nodulação (de forma diferente para as duas estirpes), geralmente, a atividade da nitrogenase sendo inibidas pelo uso de Thiram para qualquer estirpe e quantidade de células de bactéria por semente.

Dados anteriores com alfafa confirmam o efeito deletério do Thiram. TU (1981) avaliou cinco fungicidas (Benomyl, Captan, Maneb, Thiram, Zineb) para a cultura da alfafa através de dois métodos, com o uso do disco de papel de filtro e com o de vaso em casa de vegetação. O Thiram foi tóxico sobre o crescimento da bactéria em disco de papel de filtro. Com relação ao desenvolvimento e crescimento das plantas em vasos observou-se que elevados niveis de fungicidas suprimiram a nodulação quando comparadas com plantas não tratadas ou tratadas com as dosagens baixas. Thiram provocou inibição na fixação de nitrogênio, provocando redução no crescimento da parte-aérea com dosagens de $3000 \mu \mathrm{g} /$ grama e no crescimento de nódulos, com dosagens de 2500 e $3000 \mu \mathrm{g} /$ grama. Por outro lado este fungicida estimulou o crescimento da parte-aérea e da raiz quando aplicado ao nível de 200 a $500 \mu \mathrm{g} /$ grama de semente.

Esse autor considera que os resultados obtidos em laboratório com relação ao efeito de fungicidas sobre o Rhizobium devem ser vistos com restrições quando se pretende transferí-los para o campo, uma vez que o aumento do stand pode ser determinado pelo tipo de solo e condiçães experimentais na condução do trabalho. 
ODEYEMI \& ALEXANDER (1977) ressaltaram a importância da estirpe de Rhizobium e sua interação com o uso de fungicidas através do trabalho de isolamento de Rhizobium meliloti resistente ao Thiram a partir de cultura sensivel. A técnica utilizada foi a obtenção da resistência pelo cultivo em meios contendo quantidades crescentes de fungicidas. As plantas cultivadas com a estirpe resistente, na presença do Thiram $(5,0$ $\mathrm{mg} / \mathrm{g}$ sementes), cresceram tão bem quanto as plantas que não receberam fungicida no tratamento de semente. As plantas oriundas de sementes tratadas com Thiram e inoculadas com Rhizobium não resistente eram atrofiadas, cloróticas, pobremente verdes e com pequena ou ausente fixação de nitrogênio.

MÅTENSSON (1992) estudou o Rhizobium meliloti com o objetivo de testar os efeitos de alguns fungicidas (Fenpropimorph, mancozeb e benomyl) e metais pesados sobre o crescimento dessa bactéria e sua simbiose com a alfafa. $\mathrm{O}$ autor utilizou duas estirpes de Rhizobium meliloti ( a RME, isolada de um solo com manejo ecológico e a RMF, isolada de um solo exposto ao uso de agroquímicos) e vários métodos para promover a avaliação das estirpes. Neste caso o autor não encontrou diferenças nas respostas das diferentes estirpes utilizadas quanto a presença dos fungicidas testados acima.

Desta forma observa-se que os efeitos dos fungicidas no tratamento de semente de alfafa sobre o Rhizobium meliloti parecem estar extremamente ligado à estirpe utilizada. 


\subsection{Taxas de semeadura, stand uso de fungicidas para o tratamento de sementes.}

As recomendações relativas a quantidade de sementes que devem ser utilizadas por unidade de área para a implantação de um alfafal variam muito, e pelos trabalhos relacionados abaixo pode-se ter idéia da amplitude dessa variação e das previsões sobre o que pode ocorrer com o stand.

COWETT \& SPRAGUE (1962) trabalharam com densidade de stand sobre o número de hastes, peso seco por planta e produção por área. Seus dados mostram que, aumentando-se a densidade de 9 para 73 plantas $/ \mathrm{m}^{2}$ diminuiu-se o número de hastes e o peso seco por planta, mas incrementou-se a produção em 3,38 ton./ha no primeiro corte após o estabelecimento.

Ao tratar sobre as técnicas utilizadas para o estabelecimento, TESAR \& JACKOCBS (1972) revisaram trabalhos relacionados a taxas de semeadura e stands. JACKOCBS e MILLR (1970) encontraram que 220 plantas $/ \mathrm{m}^{2}$ são requeridas para produção máxima na primeira colheita. A segunda e terceira colheita tornaram-se necessárias 75 plantas $/ \mathrm{m}^{2}$ para a obtenção de produtividade máxima. MARTIN (1967) reporta como stand adequado 138 a 184 plantas $/ \mathrm{m}^{2}$. TESAR e JACKOCBS (1972) indicaram que $11,2 \mathrm{Kg}$ de sementes/ha possibilitaram a distribuição de 459 sementes $/ \mathrm{m}^{2}$, que proporcionaram stand inicial de 275 a 321 plântulas $/ \mathrm{m}^{2}$. O estabelecimento de alfafa nos USA, através de semeadura e uso de herbicidas na implantação foi avaliado através da produtividade durante a primeira colheita. Em Maine houve incremento de 1,3 ton./ha 
com aumentos da taxa de semeadura de $8.9 \mathrm{Kg} / \mathrm{ha}$ para $17,9 \mathrm{Kg} / \mathrm{ha}$. Em New York a produtividade aumentou 0,5 ton/ha com semeadura de $20,2 \mathrm{Kg}$ /ha quando comparada a taxas de $13,5 \mathrm{Kg} / \mathrm{ha}$. Em Michigam não houve incremento da produção de forragem quando se aumentou a quantidade de semente acima de $9,0 \mathrm{Kg} / \mathrm{ha}$. Em Wisconsin 13,4 $\mathrm{Kg}$ /ha foi a melhor taxa quando houve um bom preparo do solo. Em condições adversas de preparo de solo houve necessidade de aumentar essa quantidade de sementes para $17,9 \mathrm{Kg} / \mathrm{ha}$. Em Nebraska doses de 10 e $16,8 \mathrm{Kg} /$ ha produziram resultados similares quanto à máxima produtividade durante os dois primeiros anos do estabelecimento. Os autores após essa revisão concluíram que doses de $18 \mathrm{Kg} / \mathrm{ha}$ em semeaduras feitas na primavera, sem culturas acompanhantes, e com uso de herbicidas, tem contribuído para aumentar a produção no ano de plantio, nos EUA.

VAN KEUREN (1973) avaliando estabelecimento de alfafa e doses de semeadura não encontrou incremento de produção usando taxas acima de $13,4 \mathrm{~kg} / \mathrm{ha}$, quando houve controle das ervas daninhas. Todas as doses de semeadura testadas de 3,4 a $53,8 \mathrm{Kg} /$ ha proporcionaram stands semelhantes. A avaliação efetuada após sete meses da semeadura indicou stand variando de 90 a 120 plantas $/ \mathrm{m} 2$.

TRIPLETT et alli (1977) avaliando herbicidas concluiu que doses de semeadura de alfafa tendem a ser altas, 100 sementes/metro linear, mas os stands estabelecidos com 15 a 20 plantas/metro linear, espaçadas de 15 a $23 \mathrm{~cm}$ são aceitáveis. No trabalho desses autores 40 a 60 plantas $/ \mathrm{m} 2$ competiram com as daninhas e se tornaram dominantes nos pastos e 10 a 20 plantas $/ \mathrm{m} 2$ proporcionaram produções satisfatórias. Populações maiores 
do que 20 plantas/metro linear tiveram incrementos muito pequenos em produção quando avaliadas na primeira colheita.

FORNEY et alli (1985) pesquisando sistemas de rotação de culturas e eliminação de ervas daninhas em alfafa conseguiram stands de 220 a 540 plantas $/ \mathrm{m} 2$ com o uso de $16 \mathrm{Kg}$ de sementes/ha tratadas com inseticidas. Neste trabalho stands menos densos produziram plântulas com maior vigor, enquanto que em stands muito densos a competição intra-específica foi fator limitante ao estabelecimento.

TESAR e MARBLE (1977) avaliaram o estabelecimento de alfafa através de produção máxima da primeira colheita, indicando as seguintes composições para diferentes locais dos Estados Unidos: 400 plantas $/ \mathrm{m} 2$ no oeste, 140 plantas $/ \mathrm{m} 2 \mathrm{em}$ Michigam, 230 plantas $/ \mathrm{m} 2 \mathrm{em}$ Ohio, 260 plantas $/ \mathrm{m} 2 \mathrm{em}$ Illinois. Os autores acreditam que aproximadamente 150 a 250 plantas/m2 são necessárias para a máxima produção no ano de semeadura e 40 a 60 plantas $/ \mathrm{m} 2$ podem ser adequadas em stands mais velhos. Uma taxa de semeadura de $18 \mathrm{Kg} /$ ha proporciona 800 sementes $/ \mathrm{m} 2$. O estabelecimento adequado seria de 200 a 400 plântulas $/ \mathrm{m} 2$ em locais úmidos. Após um ano do estabelecimento a densidade de 200 a 300 plantas $/ \mathrm{m} 2$ seria suficiente, enquanto que para o segundo ano esse número seria de 120 a 180 plantas $/ \mathrm{m} 2$.

Esses autores citando DAVIS (1984) indicaram que 20 a $30 \mathrm{Kg}$ de sementes/ha seriam requeridos para estabelecer 320 a 640 plantas $/ \mathrm{m} 2$ nas condições da Califórnia. A sobrevivência de seedlings após o primeiro inverno está na dependência da taxa de 
semeadura que variou de 66 a $32 \%$ de sobrevivência quando a densidade de semeadura variou de 10 a $40 \mathrm{Kg} / \mathrm{ha}$, respectivamente.

No Brasil, HONDA \& HONDA (1990) recomendam $20 \mathrm{Kg}$ de semente/ha, e o stand após um ano de implantação deveria ser de 140 a 180 plantas/m2. KEPLIN \& Santos (1991) informam que no Rio Grande do Sul não foram observadas diferenças significativas na produção de matéria-seca com semeaduras de 5 a $15 \mathrm{Kg} /$ ha de sementes em linhas ou $20 \mathrm{Kg} / \mathrm{ha}$ a lanço com uso de fungicidas devido às condições de qualidade de semente, de preparo de solo, de profundidade de semeadura e da experiência do produtor com a cultura. Esses autores ainda desaconselham uso de quantidades elevadas de semente por hectare $(30$ a $50 \mathrm{Kg} / \mathrm{ha})$, pois as plantas oriundas dessa taxa de semeadura possuem um menor sistema radicular, sendo mais suscetivel ao ataque de pragas e doenças. O stand para um alfafal bem estabelecido seria de 130 a 150 plantas adultas/m2, no ano da implantação.

Ainda no Brasil, EICHELBERGER, (s.n.t.) informa que um quilo de semente possui 440000 sementes, e que a quantidade de semente por hectare tem importância relativa. A menor densidade apresenta maior número de hastes por coroa. $\mathrm{O}$ número de hastes é o mesmo usando-se $5 \mathrm{Kg} /$ ha ou $30 \mathrm{Kg} /$ ha de sementes. Para semeadura a lanço a recomendação é de 15 a $20 \mathrm{Kg} / \mathrm{ha}$.

TESAR e JACKOCBS (1972) consideram que uma semeadura é excelente quando 60 a 70\% de emergência é conseguido em áreas úmidas. Como resultado da competição, doenças, insetos, injúrias de inverno, e outras causas, o números de 
idade do alfafal e no número de plantas por unidade de área. conforme mostra a relação abaixo:

idade do stand

ano plantio

10. ano após plantio

2o. ano após plantio

3o. ano e subsequentes plantas $/ \mathrm{m}^{2}$

215 a 537

129 a 268

86 a 129

54 ou menos

Quando o stand torna-se menor que 54 plantas por metro quadrado a produção de forragem pode diminuir e o alfafal pode se tornar antieconômico.

Na Nova Zelândia trabalhos conduzidos por PURVES et alli (1987) para definir o estabelecimento de diversos cultivares de alfafa e desempenho deste quando semeadas em locais de cultivo com alfafa mostram que em taxa de semeadura de $10 \mathrm{Kg}$ /ha é colocado no plantio aproximadamente 380 sementes viáveis $/ \mathrm{m}^{2}$ assumindo-se $90 \%$ de germinação. O stand inicial dessa cultura variou de 104 a 152 plantas $/ \mathrm{m}^{2}$. Acredita-se que essa amplitude final se deva às diferentes resistências desses cultivares a nematóides. 
plântulas sobreviventes no primeiro ano é de, geralmente, 40 a $50 \%$ da semente utilizada. Esse autores encontram freqüentemente, sobrevivência de plântulas da ordem de $20 \%$ no primeiro ano. $\mathrm{O}$ uso de $11,2 \mathrm{Kg} / \mathrm{ha}$ de semente proporcionaria aproximadamente 459 sementes $/ \mathrm{m} 2$, uma boa emergência seria 275 a 321 plântulas, com estabelecimento médio de cerca de 229 plantas/m2 após o primeiro inverno.

Quanto ao efeito do uso de fungicidas sobre o stand, MYRES e RHODES (1989) avaliaram o efeito do tratamento de sementes com Metalaxyl e Pyroxyfur no controle do damping-off de alfafa causado por Phytophtohora megasperma $\mathrm{f}$ sp medicaginis. Duas semanas após o plantio foram avaliadas a \% de emergência, a \% de plantas com damping-off. Quatro semanas após o plantio foram medidas a \% de emergência e altura de plantas. Com quatro semanas o efeito da doença era evidente: a \% de emergência que era de $73 \%$ para o solo não infestado passou para $13,5 \%$ e $5,5 \%$ nos solos infestados com diferentes isolados. Quando tratou-se as sementes esses valores foram 20 a 30\% se utilizado o Pyroxyfur e 60 a $70 \%$ se empregado Metalaxyl. Como se pode notar, os fungicidas diminuiram mas nâo eliminaram os patógenos.

No Guia de Diagnóstico e Manejo da Alfafa, publicado recentemente nos Estados Unidos (1990) pela Pioneer Hi-Bred International Inc. existe a recomendação do uso de método de semeadura e da condição do solo, esperando-se sob condiçães normais a sobrevivência de apenas 30 a 40\% das plântulas no segundo ano após a implantação do alfafal. Ainda nesta publicação é apresentada uma tabela para avaliação do stand de um alfafal segundo a Universidade de Wisconsin. O stand ótimo de alfafa é baseado na 


\section{MATERIAL E MÉTODOS}

A proposta deste trabalho foi a de isolar os patógenos causadores de dampingoff em plântulas na cultura da alfafa, testar sua patogenicidade e, a partir dai, pesquisar os fungicidas utilizados para o tratamento de sementes e suas respostas quanto a fitopatologia, rizobiologia e taxas de semeadura no estabelecimento de um alfafal.

O projeto experimental foi dividido em três fases como seguem abaixo.

FASE 1: Coleta de material infestado, em campos de alfafa, com sintomas de damping-off, posterior preparo dos inóculos e teste de patogenicidade.

FASE 2: Experimentos em casa-de-vegetação para avaliar os efeitos dos fungicidas sobre as taxas de emergência, sobrevivência, produção das plantas e sobre a rizobiologia destas.

FASE 3: Experimento a campo com o objetivo de estudar vária taxas de semeadura e os efeitos do tratamento de sementes com fungicidas.

O início dos experimentos foi em 08/01/93 e o término em 31/05/94. A seguir, será colocada, por fase, a metodologia empregada nos experimentos. 


\subsection{FASE 1 .}

Nos dias 8 a 11/01/93 foram realizadas as primeiras coletas a campo. Uma coleta foi realizada na área do Departamento de Zootecnia de Ruminantes - ESALQ/USPPiracicaba, em canteiros onde a alfafa foi semeada para observação do aparecimento de sintomas relacionados ao damping-off. A outra coleta foi realizada em campo comercial de alfafa em propriedade rural situada no município de Holambra/SP. No campo procurou-se coletar plântulas, raizes, hastes e solo das regiões infestadas. Desses materiais foram isolados os patógenos.

A identificação dos patógenos foi efetuada empregando-se três técnicas.

A primeira técnica consistia em semear a alfafa em placas de Petri, colocadas em câmara úmida, com o objetivo de obter seedlings que seriam utilizadas para receberem inoculação de patógenos. As sementes de alfafa foram desinfetadas com hipoclorito de sódio diluído em água destilada a $30 \%$, durante um período de 30 segundos, depois estas foram lavadas em água destilada e colocadas para germinar em placas de Petri contendo dois discos duplos de papel umedecidos.

Foram montadas, em câmara de fluxo laminar, placas de Petri contendo água destilada, pedaços de raizes, hastes e plântulas infestadas com pedaços de folhas novas de plantas sadias e colocadas em câmara úmida para futura observação. Após 24 horas já era possível observar a presença de fungos.

Após seis dias as folhas novas que apresentaram fungos foram transferidas, em câmaras de fluxo laminar, para Placas de Petri contendo água esterelizada e plântulas 
obtidas nas placas da câmara úmida. Essas placas foram incubadas por dois ou três dias em câmara úmida. As plântulas que apresentavam crescimento de fungos foram utilizadas para fornecer pequenos pedaços, que foram desinfetados e transferidos para placas de Petri contendo meio ágar-água. Depois, de aproximadamente 5 dias, pequenos cilindros dessas placas foram transferidos para placas de Petri contendo meio B.D.A.

A segunda técnica de isolamento foi desenvolvido através do uso de solos infestados, oriundos da ESALQ e Holambra. Esses solos $(300 \mathrm{ml})$ foram colocados em becker de $1000 \mathrm{ml}$ e umedecidos com $700 \mathrm{ml}$ de água esterelizada, sendo então transferidos para câmara úmida. Após 24 horas foram colocados nesta solução de soloágua pedaços de brotos de plantas para serem infectados e posteriormente procedeu-se o isolamento dos fungos conforme a técnica anterior.

A terceira técnica foi realizada com o objetivo de se detectar a presença de Pythium nos solos. Em 12/01/93 foi semeada, em casa-de-vegetação, alfafa (semente desinfetada, conforme procedimento anterior) em caixas contendo solo autoclavado. Em 18/01/93 as plântulas haviam emergido. No dia seguinte foi colocado sobre esse solo uma camada de solo infestado contendo $20 \%$ de aveia. Em 26/01/93, foram coletadas plântulas com sintomas de tombamento, que tiveram dois destinos. Parte delas foram colocadas integralmente em placas de Petri com água destilada e em câmara úmida. Pedaços da região de transição entre o hipocótilo e o epicótilo foram seccionadas, desinfetadas superficialmente com álcool e transferidas para placas de Petri com meio 
ágar-água e depois de 4 ou 5 dias em câmara úmida novamente transferidas para placas de Petri contendo meio B.D.A.

As placas obtidas em câmara úmida em qualquer uma das fases era examinada e os crescimentos fúngicos observados. Conseguiu-se isolar neste trabalho os fungos Rhizoctorina solani e Fusarium $s p$ e não como previsto os fungos Pytium sp e Phytophthorasp.

Depois desses fungos serem isolados em B.D.A. realizou-se um ensaio para testar a patogenicidade desses agentes.

O teste de patogenicidade foi realizado na casa-de-vegatação do Departamento de Fitopatologia da ESALQ, no período de 09/02/93 a 17/03/93, em vasos de alumínio com capacidade para $2 \mathrm{~kg}$ de solo. Esses vasos receberam solo autoclavados sendo que na metade superior destes foram misturados cerca de 15 a 20 pequenos cilindros de meio BDA com os fungos isolados. Em cada vaso foi semeado 50 sementes de alfafa. Foram realizados três tratamentos (Rhizoctonia, Fusarium e Testemunha), distribuídos em quatro repetições e arranjados em delineamento experimental totalmente casualizado.

As plântulas mortas coletadas foram levadas para laboratório para se efetuar o reisolamento e avaliação de patogenicidade dos fungos isolados. Foram realizadas quatro contagens das plantas. A primeira com um semana após emergência, a segunda e a terceira após 7 e 14 dias, respectivamente e a quarta por ocasião da colheita que ocorreu 37 dias após a semeadura. Durante a colheita mediu-se a altura das plantas, o comprimento das raízes, e o peso seco da parte aérea e das raízes. 
Após a realizaçào do teste de fitopatogenicidade os inóculos foram reproduzidos da seguinte maneira para serem utilizados na fase 2 .

Grãos de trigo lavados em água corrente e colocados em erlenmeyers contendo igual volume de água destilada foram autoclavados duas vezes em dias consecutivos (1 atm durante 20 minutos a $120^{\circ} \mathrm{C}$ ). Pequenos cilindros retirados de placa de Petri com Rhizoctonia crescido em BDA foram transferidos para os erlenmeyers que foram incubados durante o tempo necessário para o aparecimento de crescimento fúngico. Para o preparo do inóculo do Fusarium foram utilizados placas de Petri onde o fungo foi cultivado. Nessas placas foi adicionado água destilada e detergente twin 80 e depois agitadas manualmente. A solução sobrenadante das placas foi coletada de onde se retirou pequenas amostras para contagem dos macro e microconídeos. A partir dessa solução foi preparada uma suspensão contendo $10^{4}$ de conídeos por litro que foi utilizada como inóculo para a segunda fase.

\subsection{FASE 2.}

$\mathrm{Na}$ Fase 2 foram realizadas duas etapas experimentais, a primeira para testar fungicidas e a segunda para estudar o efeito desses fungicidas sobre diversas estirpes de Rhizobium.

$\mathrm{Na}$ primeira etapa da fase 2 foram avaliados, em estufa, os seguintes tratamentos após inoculação com três estirpes diferentes de Rhizobium meliloti: 
1) Duas dosegens comerciais de fungicida ( $20 \mathrm{~g}$ de Rovral, princípio ativo iprodione, por $10 \mathrm{~kg}$ de semente e $60 \mathrm{~g}$ de Rhodiauram, princípio ativo Thiram, por 20 $\mathrm{kg}$ de semente) e um tratamento controle onde as sementes não receberam fungicidas.

2) Inoculação do solo com Rhizoctonia e Fusarium com os inóculos confeccionados na fase 1 e um tratamento controle sem inoculação com patógenos.

O experimento foi conduzido como um fatorial, arranjado em blocos ao acaso com 5 repetições e 9 tratamentos, totalizando 45 parcelas.

Para melhor confiabilidade dos dados esse experimento foi conduzido em duas épocas diferentes, um implantado em 30/04/93 e outro com as mesmas características implantado em 26/07/93.

\subsubsection{Inoculação e tratamento de sementes com Rhizobium meliloti para experimento em vasos com solo.}

As sementes de alfafa foram inoculadas com três estirpes diferentes de $R$. meliloti (SEMIA 116, SEMIA 134 e SEMIA 135 , IPAGRO-RS), que fazem parte da coleção de Estirpes da Seção de Microbiologia do Solo, CENA, Piracicaba-S.P. As estirpes foram cultivadas em meio liquido contendo extrato de levedura e manitol (YMB) com agitação constante a $28-30^{\circ} \mathrm{C}$, durante quatro dias. Após esse periodo o meio foi transferido para turfa comercial na proporção de $30 \%$, tomando-se o cuidado de secar, moer, esterelizar e corrigir a turfa para ph 6.8 , previamente. Esse material foi 
acondicionado em sacos plásticos que permaneceram durante um dia em temperatura ambiente e depois foi transferido para geladeira.

As sementes de alfafa, cultivar crioula, foram separadas em três lotes: um sem fungicidas, outro tratado com Rovral e outro com Rhodiauram, nas dosagens mencionadas anteriomente. As sementes e os fungicidas foram acondicionadas em copos de plásticos com tampa e agitados manual e vigorosamente. Os três lotes de semente foram inoculados (as três estirpes misturadas) com $600 \mathrm{~g}$ de inoculante/10 $\mathrm{Kg}$ de semente e tratados com quantidades iguais de carbonato de cálcio e água que tiveram a função de solução adesiva.

\subsubsection{Preparo do solo utilizado.}

O solo utilizado nos vasos foi coletado na área experimental que serviu para a instalação dos experimentos da Fase 3. Esse solo foi autoclavado e recebeu posteriormente a quantidade de $1 \mathrm{ml}$ de solução nutritiva de micronutrientes $/ \mathrm{Kg}$ de solo, uma vez que em testes preliminares, as plantas apresentaram sintomas de deficiência de micronutrientes. O solo foi acondicionado em 60 sacos plásticos pretos e grossos com capacidade para $3 \mathrm{Kg}$.

\subsubsection{Plantio e irrigação.}

Foram semeadas em 30/04/93 e 36/07/93 dez sementes por vaso e não foi realizado o desbaste. A irrigação foi feita controlando-se a umidade dos vasos devido a diferença no número de plantas entre as parcelas em consequência dos tratamentos. No 
inicio, os vasos foram irrigados com pulverizador para que as sementes não fossem arrastadas. Durante o plantio foram colocados os inóculos confeccionados na fase 1. A Rhizoctonia foi inoculada através das sementes de trigo infectadas que foram colocadas junto das sementes de alfafa, na proporção 1:1. O Fusarium foi inoculado através da aplicação de $40 \mathrm{ml}$ por vaso da suspensão preparada na fase 1 .

\subsubsection{Parâmetros mensurados do experimento em vasos com solo.}

Após uma semana do plantio, foi contado o número de plantas vivas e mortas e assim consecutivamente até não haverem mais plantas mortas. Com um mês após a emergência foi medido a altura das plantas. Na colheita (30/06/93 e 05/10/93) foi medido a altura das plantas, essas foram cortadas e acondicionadas em saco de papel para realização do peso seco da parte aérea e das raizes depois de lavadas, e secas por 48 horas em estufa de circlulação forçada a $60^{\circ} \mathrm{C}$.

Não foi observada nodulação das plantas, sugerindo interferência dos niveis de $\mathrm{N}$ mineral ( $\mathrm{N}$ amoniacal e $\mathrm{N}$ nitríco) no solo. Amostras de solos foram coletadas para estas determinações constatando-se níveis elevados de $\mathrm{N}$ mineral no solo (Tabela 4). Devido a este fato foi realizado o mesmo ensaio, no mês de julho, segundo metodologia já descrita, utilizando um mistura do solo da área experimental com areia na proporção 1:1. Com este procedimento conseguiu-se diminuir o $\mathrm{N}$ mineral para níveis de aproximadamente $20 \mathrm{ppm}$, que ainda não foram suficiente baixo para garantir a nodulação das plantas. 
Devido as dificuldades encontradas na pesquisa com relação a interação dos níveis de $\mathrm{N}$ do solo e a inoculação, optou-se por trabalhar com vasos de Leonard, uma vez que esta técnica permite o uso de solução nutritiva com quantidades controladas de nitrogênio.

Nesta segunda etapa da fase 2 foram efetuadas algumas modificações em decorrência dos resultados obtidos nos dois primeiros experimentos que utilizaram solo. Os seguintes fatores foram estudados:

a) Três estirpes de Rhizobium (SEMIA 116, 134 e 135, SPAGRO, RS).

b) Quatro diferentes usos de fungicidas (Thiram na dosagem de $60 \mathrm{~g}$ de Rhodiauram $/ 10 \mathrm{Kg}$ de semente no tratamento de semente, Iprodione na dosagem de $20 \mathrm{~g}$ de Rovral/10 $\mathrm{Kg}$ de semente tratamento de semente, Iprodione aplicado sobre a superficie dos vasos na dosagem de $1,5 \mathrm{Kg}$ do produto comercial Rovral por hectare diluído em 1000 litros de calda e um tratamento controle sem o uso de fungicidas).

Foram, então, utilizados 12 tratamentos com 5 repetições totalizando 60 parcelas. O delineamento experimental foi o de blocos ao acaso.

\subsubsection{Inoculação e tratamento de sementes com fungicidas para os vasos de} Leonard.

O tratamento e inoculação com Rhizobium meliloti de sementes foram efetuados conforme metodologia já descrita na primeira etapa da fase 2 , sendo que neste caso foram usadas as estirpes em lotes diferenciados, conforme o tratamento. 
Após aproximadamente uma semana da emergência das plântulas foi realizada a aplicação do fungicida Rovral, através do uso de pipeta irrigando-se a superficie dos vasos de Leonard.

\subsubsection{Preparo das Vasos de Leonard}

Os vasos, que são separados em dois recipientes interligados, um para acondicionar a solução nutritriva e o outro para acondicionar a vermiculita e o quartzo, foram autoclavados depois de montados e abastecidos com a seguinte solução nutritiva:

Solução nutritiva estoque (diluição 1:5, litro solução estoque: água, para os primeiros 15 dias após plantio e depois diluição 1:3, até a colheita).
$\mathrm{MgSO}_{4} \cdot 7 \mathrm{H}_{2} \mathrm{O}(1 \mathrm{M})$
$40 \mathrm{ml}$
$\mathrm{K}_{2} \mathrm{SO}_{4}(0,5 \mathrm{M})$
$40 \mathrm{ml}$
solução de micronutrientes*
$20 \mathrm{ml}$
solução de Fe-EDTA**
$20 \mathrm{ml}$
$\mathrm{K}_{2} \mathrm{HPO}_{4}(1 \mathrm{M})$
$30 \mathrm{ml}$
$\mathrm{CaSO}_{4} \cdot 2 \mathrm{H}_{2} \mathrm{O}$
$6,88 \mathrm{~g}$
$\mathrm{NH}_{4} \mathrm{NO}_{3}(1 \mathrm{M})$
$1 \mathrm{ml} /$ litro de solução final

* A solução de micronutrientes utilizada foi a seguinte:
$\mathrm{H}_{3} \mathrm{BO}_{3}$
$2,86 \mathrm{~g}$
$\mathrm{MnSO}_{4} \cdot 4 \mathrm{H}_{2} \mathrm{O}$
$2,03 \mathrm{~g}$
$\mathrm{ZnSO}_{4} \cdot 7 \mathrm{H}_{2} \mathrm{O}$
$0,22 \mathrm{~g}$
$\mathrm{CuSO}_{4} \cdot 5 \mathrm{H}_{2} \mathrm{O}$
$0,08 \mathrm{~g}$
$\mathrm{H}_{2} \mathrm{MoO}_{4} \cdot 2 \mathrm{H} 2 \mathrm{O}$
$0,09 \mathrm{~g}$
$\mathrm{H}_{2} \mathrm{O}$ destilada
$1.000 \mathrm{~g}$ 
** A solução de Fe-EDTA utilizada foi a seguinte:

$\mathrm{FeCl} 3(4 \mathrm{~g} / \mathrm{L}) \quad 16,8 \mathrm{ml}$

EDTA Na. $2 \mathrm{H}_{2} \mathrm{O} \quad 2.0 \mathrm{~g}$

$\mathrm{H}_{2} \mathrm{O}$ destilada $\quad 1.000 \mathrm{ml}$

Toda vez que os vasos foram reabastecidos utilizou-se solução nutritiva autoclavada, para evitar riscos de contaminação entre estirpes.

\subsubsection{Plantio nos vasos de Leonard.}

Em cada vaso de Leonard foram semeadas 5 sementes. Na primeira semana após a emergência foi realizado um desbaste deixando-se apenas 2 plantas por vaso.

\subsubsection{Parâmetros mensurados do experimento com vasos de Leonard.}

A altura das plantas foi obtida 15 dias após emergência e o experimento foi encerrado aos 60 dias da semeadura. Nessa ocasiào mediu-se a altura das plantas, e efetuou-se a colheita das plantas ao nível da inserção da raiz. O material colhido foi acondicionado em sacos de papel e levados para secagem em estufa de circulação forçada de ar a $60^{\circ} \mathrm{C}$. Foi realizado a determinação do peso-seco da parte-aérea e o teor de nitrogênio conforme modificação do Technicon Industrial Method número 128-72A (determinação calorimétrica).

Em seguida as raízes foram colocadas em frascos de $500 \mathrm{ml}$, apropriados para uso em cromatografia de chama, com o objetivo de se avaliar a Atividade de Redução do Acetileno. Após essa determinação as raízes foram lavadas, e acondicionadas em sacos plásticos e guardadas em geladeira. Foi contado o número de nódulos por parcela, e estes foram acondicionados em pequenos frascos e levados para estufa de circlulação de ar 
forçada a $60^{\circ} \mathrm{C}$ para determinação do seu peso seco. $\mathrm{O}$ peso seco das raizes também foi determinado.

Esse ensaio também foi conduzido duas vezes, em épocas diferentes, sendo que no segundo experimento, após o desbaste, cada vaso ficou com 5 plantas.

\subsection{FASE 3.}

Nesta terceira fase foi avaliado o uso de fungicidas no tratamento de semente e sua interação com a taxa de semeadura.

Foram utilizadas seis taxas de semeadura, 5, 8,10, 15, 20 e $25 \mathrm{Kg}$ sementes/ha, associadas com o uso de dois fungicidas, Thiram (Rhodiauram) e Iprodione (Rovral), nas dosagens utilizadas na fase 2 , e um tratamento testemunha. A alfafa variedade crioula foi inoculada com a mistura das três estirpes de Rhizobium meliloti testadas anteriormente.

O delineamento experimental utilizado foi o de blocos ao acaso com 18 tratamentos e 4 repetições ( 6 taxas de semeadura $\times 2$ tipos de fungicida +1 controle $\times 4$ repetições), totalizando 72 parcelas.

As sementes foram peletizadas segundo Keplin e Santos (1991) e os fungicidas aplicados durante a peletização.

\subsubsection{Unidades Experimentais.}

Essa fase experimental foi realizada no campo, em 72 canteiraos de $0,8 \mathrm{~m} \times 2,0$ m. Cada canteiro continha 4 ruas espaçadas de $20 \mathrm{~cm}$.

O solo da área foi analisado e recebeu correção com calcário dolomítico para elevação da saturação por bases a $80 \%$. Os níveis de fósforo e potássio não foram corrigidos por se apresentarem em níveis adequados conforme demonstra os resultados referente a análise do solo da área experimental, a seguir. 
Resultados da análise de solo da área experimental.

\begin{tabular}{|c|c|c|c|c|c|c|c|c|c|c|}
\hline ph & $\mathrm{MO}$ & $\mathrm{P}$ & $\mathrm{K}$ & $\mathrm{Ca}$ & $\mathrm{Mg}$ & $\mathrm{H}+\mathrm{Al}$ & $\mathrm{Al}$ & soma de & $\mathrm{CTC}$ & sat. \\
& & $\begin{array}{c}\text { resina } \\
\mathrm{ppm}\end{array}$ & & & & & & $\begin{array}{c}\text { bases } \\
\text { bases }\end{array}$ & \\
\hline & & & \multicolumn{8}{|c|}{ eqmg/100ml } \\
\hline 5,3 & 2,7 & 24 & 0,51 & 5,1 & 2,0 & 2,2 & 0,0 & 7,61 & 9,81 & 77,58 \\
\hline
\end{tabular}

A adubação de plantio foi de $120 \mathrm{Kg} \mathrm{P}_{2} \mathrm{O}_{5}$ e $90 \mathrm{Kg}$ de $\mathrm{KCl}$ por hectare. Nesta adubação também foi realizada uma aplicação de micronutrientes, com o uso de $40 \mathrm{Kg}$ de Borogran, $20 \mathrm{Kg}$ de sulfato de zinco e $15 \mathrm{Kg}$ de sulfato de cobre por hectare.

Para diminuir os efeitos do alto teor de Nitrogênio do solo a área foi cultivada com sorgo por um mês antes da semeadura de alfafa. Após a incorporação do sorgo foi coletado solo para análise do teor de $\mathrm{N}$ mineral constatando-se que esse nível ainda era elevado e ao redor de $25 \mathrm{ppm}$. Procurou-se, então, reduzir esses níveis de $\mathrm{N}$ no solo através da incorporação de palha de arroz, para promover a imobilização do nitrogênio através da elevação da relação $C: N$.

\subsubsection{Inoculação de patógenos.}

O preparo dos patógenos foi realizado da mesma maneira que na fase 2 . A inoculação ao nível de campo foi realizada empregando-se $40 \mathrm{ml}$ de solução com Fusarium por metro linear de linha de plantio. A semente de trigo infectada com a Rhizoctonia foi colocada no sulco de plantio próximas às sementes de alfafa. 


\subsubsection{Plantio.}

O plantio foi realizado manualmente, após aplicação do fertilizante a $3 \mathrm{~cm}$ de profundidade, enquanto as sementes foram localizadas a $1,5 \mathrm{~cm}$.

\subsubsection{Irrigação.}

Nos primeiros dias após o plantio a irrigação era aplicada por períodos de 20 a 30 minutos, para que não houvesse encharcamento e escorrimento de água.

\subsubsection{Controle de Ervas Daninhas.}

As ervas daninhas foram controladas através de capina manual a cada uma ou duas semanas conforme a necessidade.

\subsubsection{Parâmetros mensurados.}

Foi realizada a pesagem de 100 sementes em 8 repetições conforme BRASIL (1992) para se determinar o número de sementes de alfafa $/ \mathrm{Kg}$. O coeficiente de variação foi de $1,56 \%$ e o número médio de sementes/Kg foi de 411692 .

As taxas de emergência no primeiro experimento foram prejudicadas, entretanto efetuou-se a contagem de plântulas antes da área ser capinada e revolvida para reinstalação do experimento após 15 dias.

Após a semeadura em 4 linhas, efetuou-se, depois de 15 dias, a contagem das plântulas nas duas linhas centrais de cada canteiro. Após uma semana foi realizado a segunda contagem e determinação do número e altura das plantas. A colheita foi realizada aos 55 dias do plantio quando o stand apresentava $10 \%$ de florescimento. Colheu-se um metro linear nas duas ruas centrais de cada canteiro. A parte-aérea foi colocada em sacos de papel e secas em estufa de circulação de ar forçada a $60^{\circ} \mathrm{C}$ por 48 
horas. $\mathrm{O}$ nitrogênio doi determinado conforme Technicon Industrial Method número 218-72A.

As raizes foram escavadas, lavadas e secas em estufa de circulação forçada de ar a $60^{\circ} \mathrm{C}$. 


\section{RESULTADOS E DISCUSSĀO}

\subsection{Fase 1 - Coleta do material infestado em campos de alfafa, com sintomas de damping-off, posterior preparo dos inóculos e teste de patogenicidade.}

Os fungos isolados como causadores de damping-off em campos de alfafa na área experimental da ESALQ e em campos comerciais da Holambra, SP, foram a Rhizoctonia solani e o Fusarium sp independente das três técnicas empregadas neste trabalho. A Figura 1 mostra plântulas que sofreram damping-off devido ao ataque do Fusarium sp, essas plântulas apresentaram tombamento e apodrecimento das suas radículas, sendo que em alguns casos a região de transição entre o hipocólito e o epicótilo tornou-se avermelhada. A Figura 2 mostra plântulas atacadas pela Rhizoctonia solani, que também sofreram tombamento, tornando-se, marrons e com apodrecimento das radículas, hipocólito e, às vezes, até do epicótilo. $\mathrm{O}$ apodrecimento em vasos ou em condições de campo é muito rápido, ocorrendo em torno de dois ou três dias.

Os resultados do teste de fitopatogenicidade são apresentados e discutidos nas Figura 3 e Tabelas 1 e 2 , onde estes são colocados de maneira descritiva. 


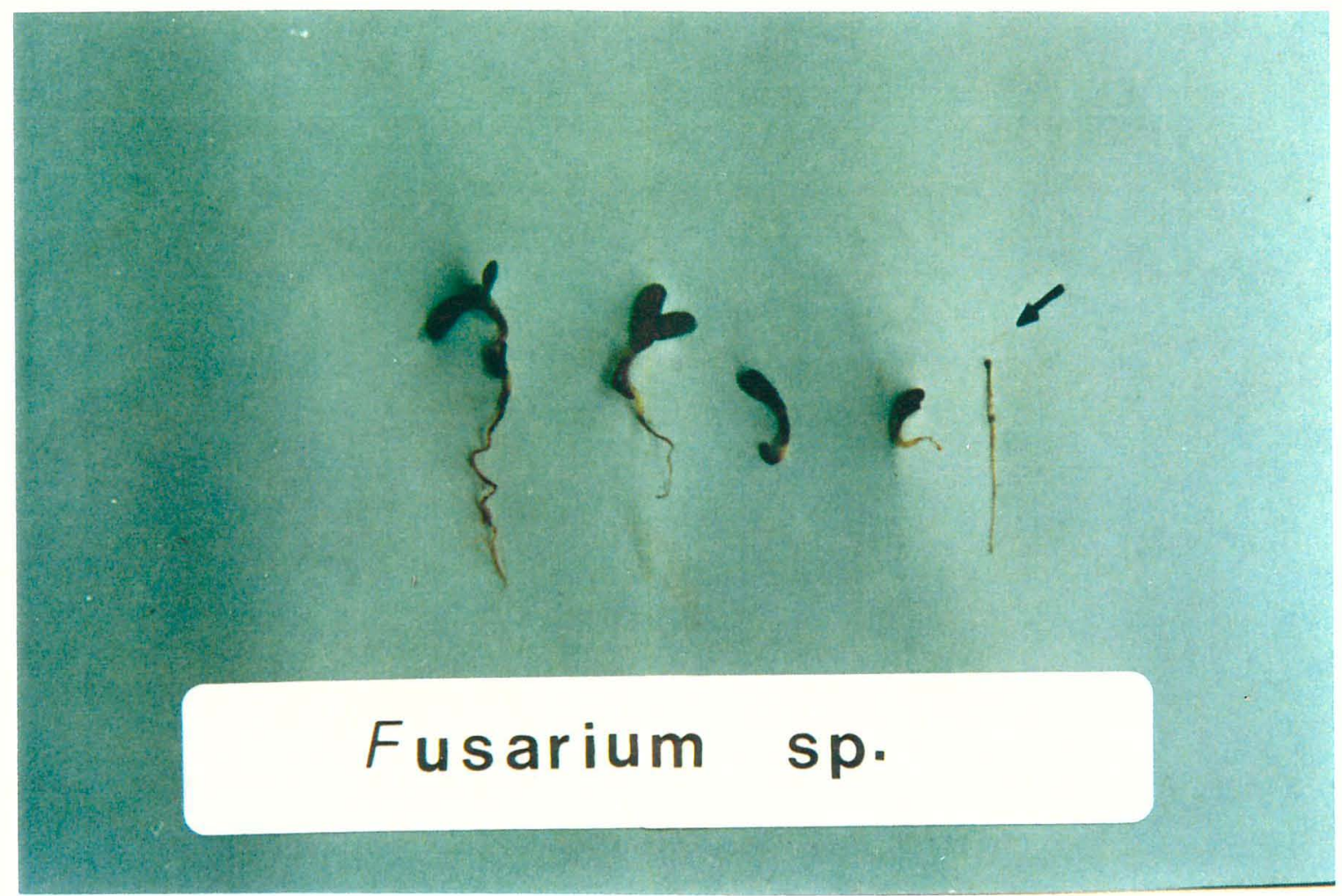

Figura 1. Plântulas com sintoma de ataque de Fusarium.

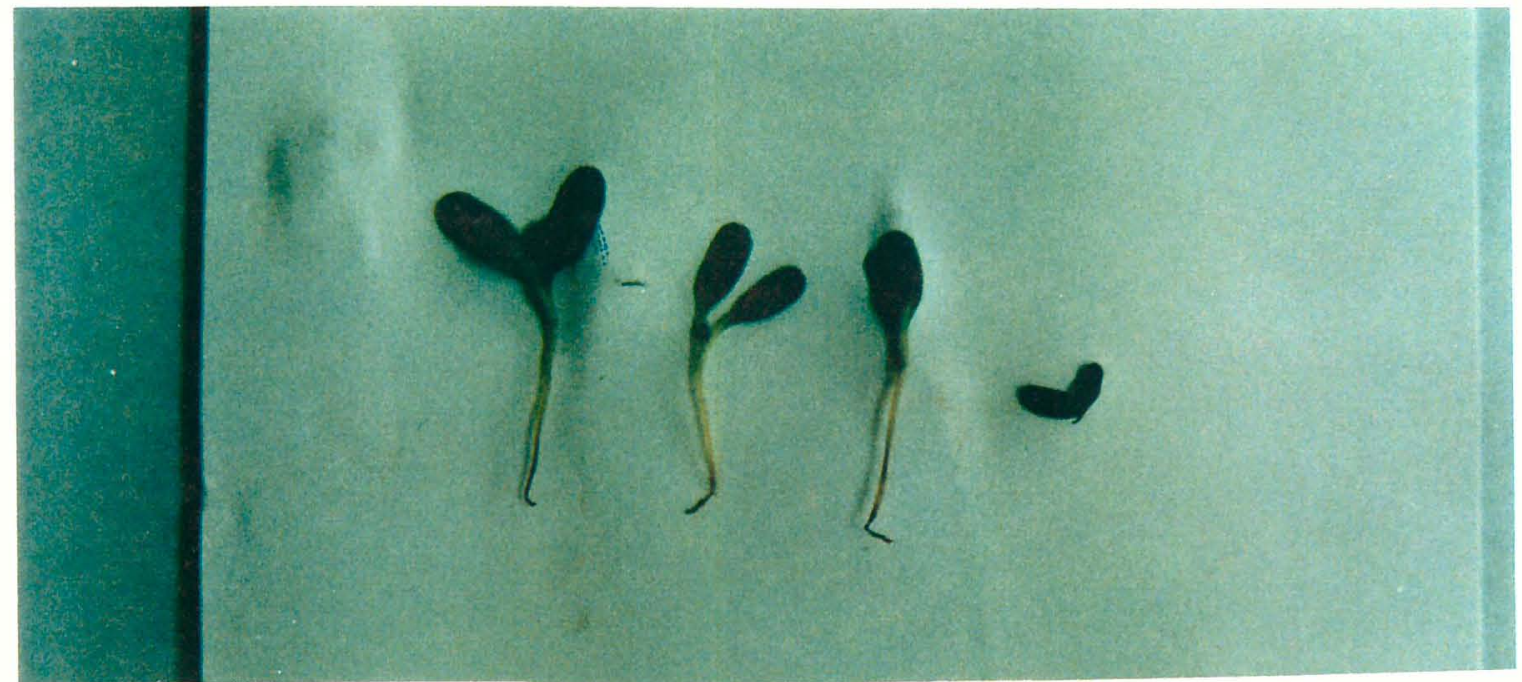

\section{Rhizoctonia solani}

Figura 2. Plântulas com sintoma de ataque de Rhizoctonia. 


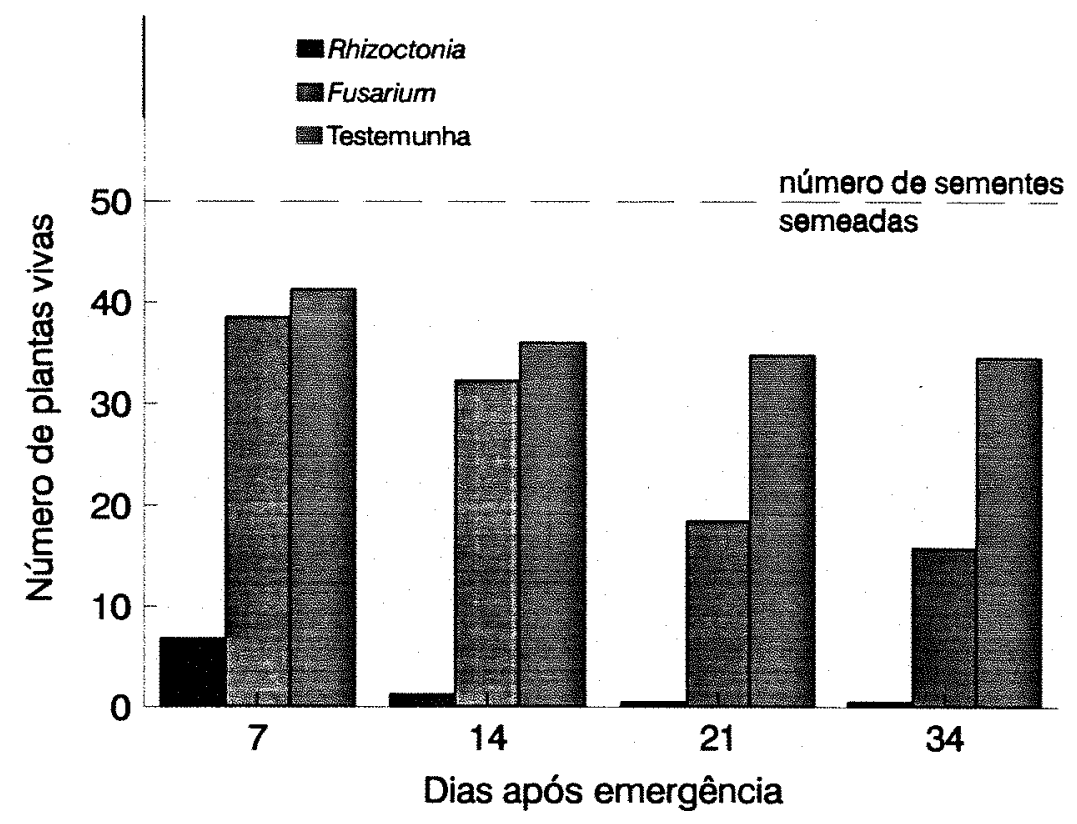

Figura 3 . Avaliação do número de plantas vivas durante o teste de patogenicidade em vasos sob casa-de-vegetação com Rhizoctonia solani e Fusarium sp. média de quatro repetições.

Tabela 1. Avaliação do número médio de quatro repetições de plantas vivas após 37 dias após semeadura, da \% emergência (número de plantas nascidas após 15 dias de plantio/50 sementes plantadas) e da \% de sobrevivência (número de plantas vivas até 37 dias após semeadura/50 sementes semeadas) do teste de patogenicidade.

\begin{tabular}{lccc}
\hline Tratamentos & $\begin{array}{c}\text { número médio } \\
\text { de plantas vivas }\end{array}$ & \% emergência & \% sobrevivência \\
\hline Rhizoctonia & 0,50 & 76,0 & 1,0 \\
Fusarium & 15,75 & 82,0 & 31,5 \\
Testemunha & 34,50 & 86,5 & 69,0 \\
\hline
\end{tabular}


Tabela 2. Altura média da parte-aérea, comprimento médio das raizes, peso-seco médio por vaso da parte-aérea e peso-seco médio por vaso da raiz do número médio de quatro repetições de plantas vivas após 37 dias da semeadura do experimento em vasos do teste de fitopatogenicidade.

\begin{tabular}{lcccc}
\hline \multirow{2}{*}{ Tratamento } & & & \multicolumn{2}{c}{ Peso - seco } \\
\cline { 4 - 5 } & altura da parte & comprimento & parte-aérea & raiz \\
& aérea & raizes $(\mathrm{cm})$ & $(\mathrm{g})$ & $(\mathrm{g})$ \\
\hline Rhizoctonia & 2,06 & 2,00 & 0,02 & 0,005 \\
Fusarium & 12,03 & 17,89 & 0,81 & 0,320 \\
Testemunha & 10,79 & 13,66 & 1,51 & 0,550 \\
Média geral & 8,29 & 11,18 & 0,78 & 0,870 \\
\hline
\end{tabular}

Durante os trabalhos de isolamento dos fungos que provocavam o damping-off nos campos de alfafa do Departamento de Zootecnia da Escola Superior de Agricultura Luiz de Queiroz e na fazenda de produção comercial de feno de alfafa em Holambra, $\mathrm{SP}$, foram isolados os patógenos Rhizoctonia solani e Fusarium sp. Provalvelmente o não aparecimento dos demais fungos possíveis causadores de damping-off na alfafa esteja relacionado com as temperaturas ótimas de crescimento. Assim a Phytophthora possui crescimento desfavorável a temperaturas mais altas, tendo como temperatura ótima de crescimento 24 a $27^{\circ} \mathrm{C}$ (ERWIN, 1990), enquanto que o Pythium também é favorecido por temperaturas mais amenas promovendo damping-off de pré-emergência em temperatura ótima de $16^{\circ}$ e de pós emergência em temperatura de 24 a $28^{\circ} \mathrm{C}$ (GRAU, 1990), a Aphanomyces requer temperaturas entre 16 e $20^{\circ} \mathrm{C}$ (GRAU, 1990). A 
Rhizoctonia e o Fusarium são favorecidos por temperaturas mais altas, sendo as temperaturas ótimas para crescimento entre 25 e $30^{\circ} \mathrm{C}$ e $25^{\circ} \mathrm{C}$, respectivamente (ERWIN, 1990).

Sendo assim para o Estado de São Paulo, acredita-se haver maior possibilidade de aparecimento dos fungos favorecidos por temperaturas mais elevadas, principalmente no verão época em que foi realizada as coletas do material infestado. Provavelmente as semeaduras realizadas no inverno em período seco onde as temperaturas são mais amenas a ocorrência de fungos seria alterada em relação a observada por essa coleta, devendo-se considerar que, neste caso onde pode-se controlar as irrigações e consequentemente a umidade no solo, o ataque por fungos tende a ser menor, pois normalmente esses microrganismos são favorecidos por umidade excessiva.

Os dados obtidos no teste de fitopatogenicidade apresentados nas Tabelas 1 e 2 mostram que a Rhizoctonia possui um efeito mais drástico sobre a semeadura da alfafa que o Fusarium, provocando maior redução na emergência (76\% de emergência para Rhizoctonia contra $82 \%$ para o Fusarium enquanto a testemunha apresentou $86,5 \%$ de emergência).

Além do efeito mais prejudicial da Rhizoctonia sobre a emergência das plântulas esse patógeno tem efeito depressivo na \% de sobrevivência da alfafa. Assim, a Rhizoctonia reduziu a sobrevivência das plantas para $1 \%$ enquanto o Fusarium provocou a redução do stand para $31,5 \%$, sendo que $69 \%$ das plântulas sobreviveram na testemunha.

Esses valores estão dentro dos resultados observados nos trabalhos conduzidos por HANCOCK (1983) na Califórnia, onde o autor encontrou sobrevivência (obtida através da subtração da \% de damping-off de pós-emergência da \% de emergência) tão baixas quanto $4,1 \%$ e $8,9 \%$ respectivamente para a Rhizoctonia e o Fusarium, quando 
trabalhou com níveis altos de intensidade de inóculo (2500 macroconídios de Fusarium/g solo seco e 141 micélios/100 g solo seco).

$\mathrm{Na}$ Tabela 2 pode-se observar que a Rhizoctonia e o Fusarium provocaram redução no peso seco da parte aérea da alfafa em $98 \%$ e $46,3 \%$ respectivamente. Essa redução apresentada no peso seco da parte aérea para o Fusarium foi semelhante aos $45 \%$ observados por HANCOCK (1983) em plantas com raízes bifurcadass atacadas por Pythium com 105 dias de idade. No trabalho deste autor essa diferença se prolongou nos próximos dois anos seguintes para os dois cultivares testados, Moapa 69 e Lahonton.

O peso seco das raízes foi reduzido em $99 \%$ e $41,8 \%$ pela Rhizoctonia e Fusarium, respectivamente. As reduções no peso seco da parte aérea e das raízes provocadas pela Rhizoctonia foram drásticas provavelmente em consequência da elevada densidade de inóculo decorrente da forma de inoculação utilizada neste trabalho, que culminou em reduções na \% de sobrevivência semelhante àquelas obtidas em outros trabalhos quando utilizou-se níveis altos de inoculação.

As reduções na altura da parte aérea e no comprimento das raízes ocorreram somente nas plântulas atacadas pela Rhizoctonia. Essas plantas apresentaram 2,06 e 2,02 $\mathrm{cm}$ na altura e comprimento de raízes, respectivamente, enquanto esses valores foram 10,7 e 13,6 cm para as plantas testemunhas. Em plantas com um mês de idade RHODES \& MYRES (1989) observaram uma redução de $6,6 \mathrm{~cm}$ de altura da parte aérea para 2,4 e $1,9 \mathrm{~cm}$ quando as plantas foram infestadas com dois isolados do fungo Phytophthora.

\subsection{Fase 2 - Experimentos em casa-de-vegetação para avaliar os efeitos dos fungicidas sobre as taxas de emergência, sobrevivência, produção das plantas e sobre a rizobiologia destas.}


O objetivo inicial desta fase foi o de testar todos os parâmentros acima através de um único experimento conduzido em casa-de-vegetação em vasos com solo, entretanto, devido ao tipo de solo disponível foi necessário a divisão desta fase em dois tipos de experimento, sendo o segundo tipo conduzido em vasos de Leonard. O solo utilizado possuía níveis consideráveis de matéria-orgânica $(2,7 \%)$ conforme pode-se observar nos resultados da análise apresentados no Material e Métodos. Esse fato possivelmente proporcionou, em função das altas temperaturas e condições de umidade favorável a mineralização de $\mathrm{N}$ orgânico, resultando, como pode ser observado na Tabela 3 em níveis altos de $\mathrm{N}$ mineral que impedem o processo de infecção e formação dos nódulos nas raízes.

Tabela 3. Teores de Nitrogênio Mineral no Solo (ppm).

\begin{tabular}{cc}
\hline Tratamento & N mineral \\
\hline Fusarium e ausência de fungicida & 70,50 \\
Rhizoctonia e ausência de fungicida & 47,15 \\
Ausência de fungo e de fungicida & 42,03 \\
Fusarium e Iprodione & 48,12 \\
Rhizoctonia e Iprodione & 99,91 \\
Ausência de fungo e Iprodione & 42,59 \\
Fusarium e Thiram & 63,29 \\
Rhizoctonia e Thiram & 75,81 \\
Ausência de fungo e Thiram & 65,34 \\
\hline Média geral & 61,64
\end{tabular}


Foi realizada mais uma tentativa para usar este solo, adicionando-se um terço de areia na montagem dos vasos. Essa prática possibilitou resultados dos teores de $\mathrm{N}$ mineral ao redor de 20 a $25 \mathrm{ppm}$, ainda insuficientes para proporcionar um efeito razoável na infeç̧ão e formação dos nódulos. O nivel onde começa haver depressão na formação dos nódulos está em torno de $2 \mathrm{mM}$ de nitrato, ou seja, $28 \mathrm{ppm}$ de $\mathrm{N}$ nítrico. (STREETER, 1988).

Os parâmetros mensurados nestes dois experimentos usando vasos com solo em casa-de-vegetação, serviram, portanto, para ánalise do efeito fitopatológico dos fungos Rhizoctonia e Fusarium e sua interação com os fungicidas Iprodione e Thiram.

Foi utilizado o método de Cochram (1954) para grupos de experimentos, citado por Pimentel (1987), para testar a viabilidade de uma análise conjunta das variáveis experimentais, com o uso de resíduos específicos. Dessa forma foi possivel agrupar as seguintes variáveis: peso-seco da parte-aérea (ps pa), peso-seco das raízes (ps raiz), altura das plântulas 21 dias após emergência (alt 21), altura das plantas na colheita (alt c), emergência e sobrevivência. A variável peso-seco da raiz foi transformada para $\sqrt{\text { psraiz }}+$ constante para obtenção de melhor homogeneidade da variância.

Os resultados obtidos para ps pa, ps raiz, alt 21 e alt c são apresentados na Tabela 4. 
Tabela 4. Resultados médios obtidos do peso seco da parte aérea (pspa), peso seco da raiz (psraiz), altura aos 21 dias e altura na colheita nos experimentos de vasos com solo da Fase 2 conduzidos em duas épocas.

\begin{tabular}{lcccc}
\hline Tratamento & $\begin{array}{c}\text { PSPA } \\
(\mathrm{g})\end{array}$ & $\begin{array}{c}\text { PS raiz* } \\
(\mathrm{g})\end{array}$ & $\begin{array}{c}\text { ALT 21 } \\
(\mathrm{cm})\end{array}$ & $\begin{array}{c}\text { ALT C } \\
(\mathrm{cm})\end{array}$ \\
\hline FI & 2,76 & 1,29 & 9,41 & 27,15 \\
FØ & 2,58 & 1,06 & 8,39 & 28,23 \\
FT & 2,43 & 1,05 & 8,93 & 23,29 \\
OI & 2,62 & 1,06 & 10,37 & 25,82 \\
OØ & 2,99 & 1,29 & 9,73 & 25,15 \\
OT & 2,15 & 1,33 & 9,00 & 22,27 \\
RI & 1,08 & 0,22 & 5,76 & 28,81 \\
R & 1,12 & 0,24 & 5,16 & 22,56 \\
RT & 1,69 & 0,52 & 5,26 & 24,00 \\
\hline Média geral & 2,16 & 0,89 & 8,00 & 25,24 \\
CV(\%) & 36,9 & 31,55 & 37,46 & 37,40
\end{tabular}

* o CV(\%) é relativo aos dados transformados, enquanto que os outros valores são os originais.

onde: $\quad$ I $=$ Iprodione $\quad T=$ Thiram $\quad \varnothing=$ ausência de fungicida

$\mathrm{F}=$ Fusarium $\quad \mathrm{R}=$ Rhizoctonia $\mathrm{O}=$ ausência de fungo

Para o PSPA os resultados obtidos da análise conjunta da variância mostram que não houve interação entre os fungos e fungicidas empregados, não havendo efeito do fator fungicida no tratamento de sementes, enquanto que houve diferença significativa no teste $\mathrm{F}(\mathrm{p}=0,0281)$ quanto ao PSPA em função do fungo inoculado. Neste caso aplicando-se o (REGW) Ryan-Einot-Gabriel-Welsch teste (SAS 1987) para 
diferenciação das médias, o Fusarium e a testemunha não diferiram entre si mas foram diferentes da Rhizoctonia, que promoveu um efeito depressivo na produção de matéria seca da parte aérea como aponta a Figura 4 graficamente.

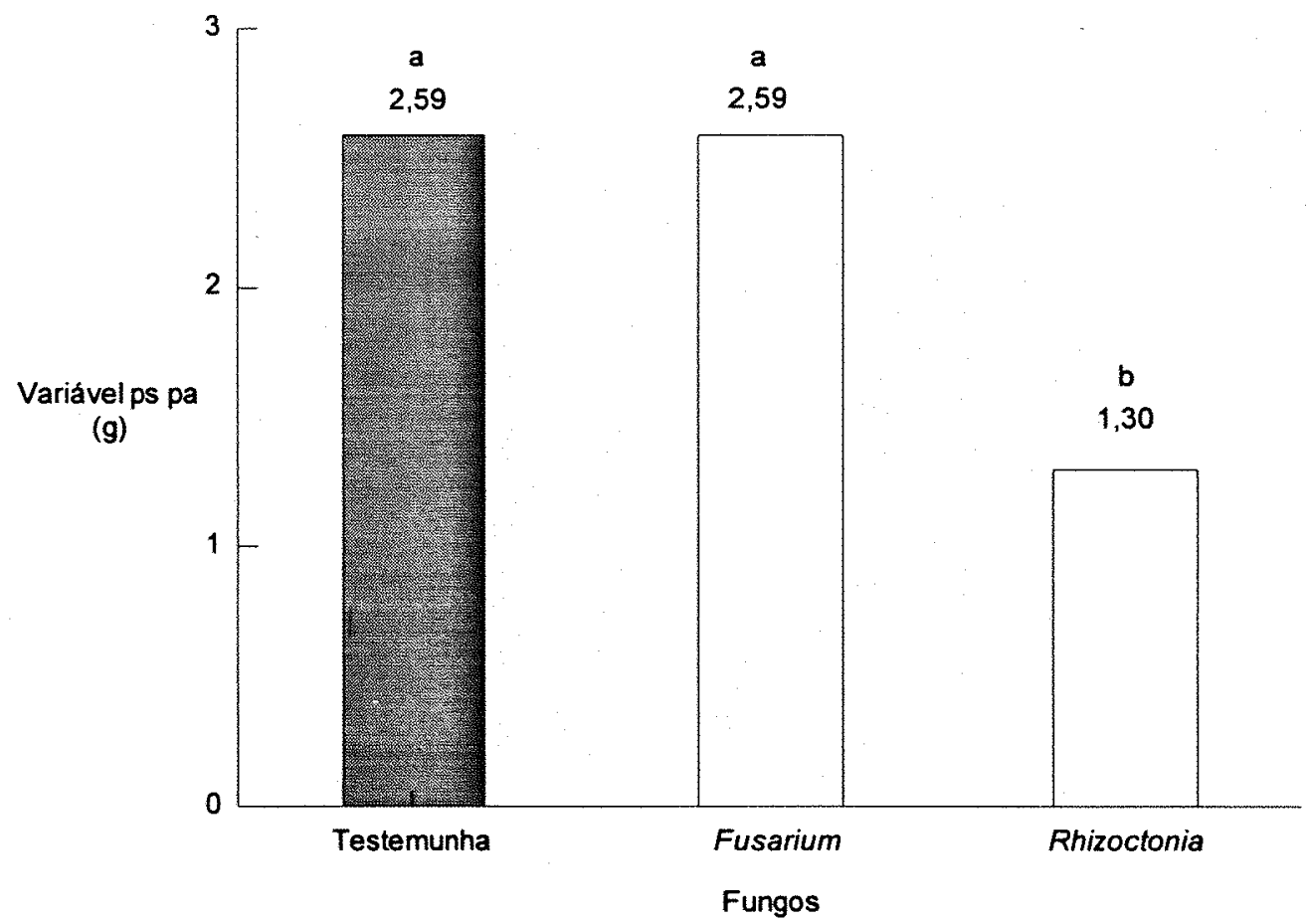

Figura 4. Peso-seco da parte-aérea em gramas para inoculação com diferentes fungos. Médias seguidas pela mesma letra não diferem significativamente pelo teste de REGW ao nível de 5\%.

Para o ps raiz os resultados da análise conjunta da variância mostram que não houve interação entre o fungo e o fungicida e diferença significativa entre os fungicidas e o controle. Entretanto, houve diferença significativa entre os fungos utilizados no teste F $(p=0,0847)$. Após aplicação do teste REGW (SAS 1987) para diferenciação das médias dos dados transformados, observou-se que a testemunha e os tratamentos que 
receberam inoculação com Fusarium não diferem entre si mas diferem da Rhizoctonia ao nível de $95 \%$ de probabilidade conforme a Figura 5.

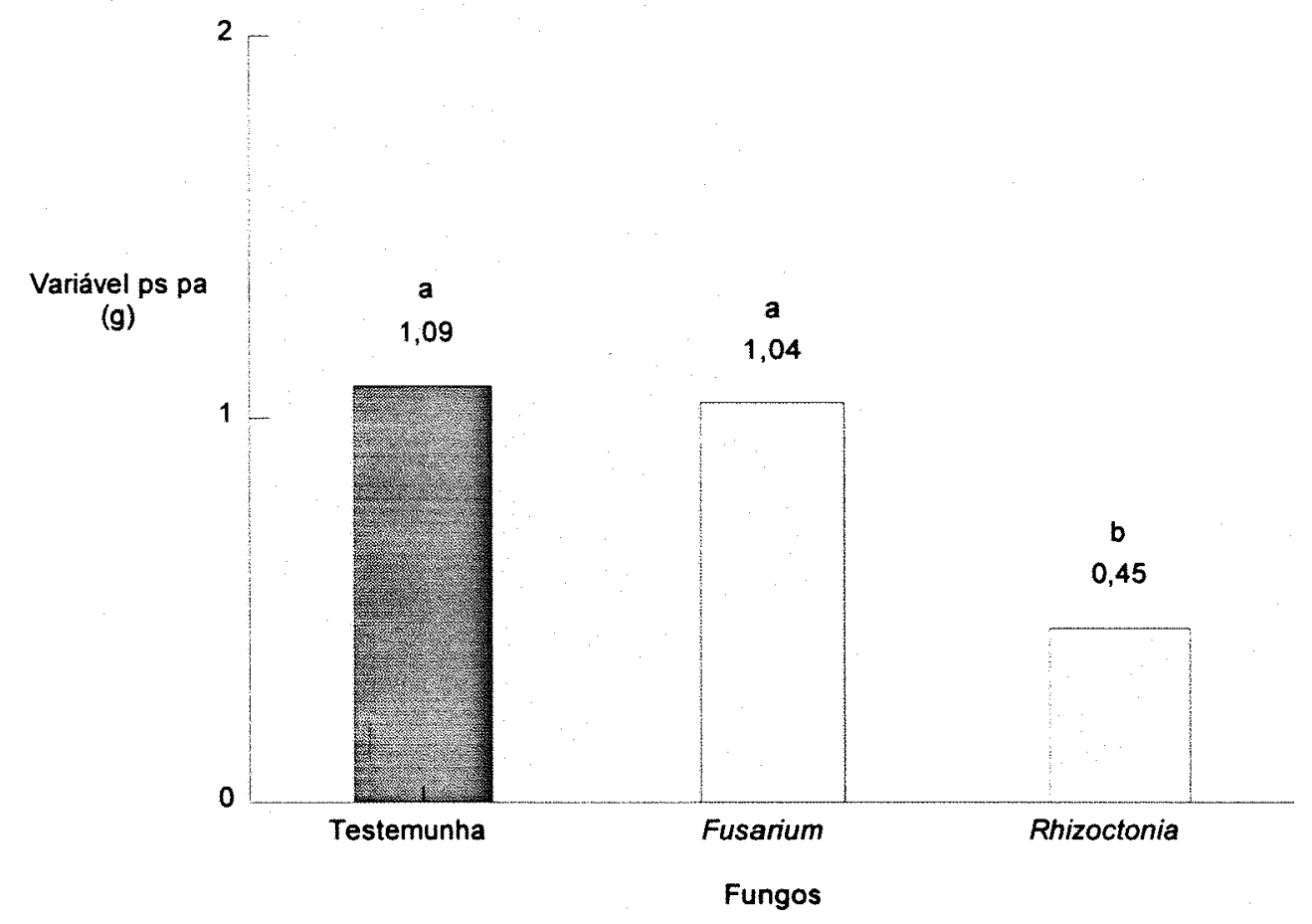

Figura 5. Peso-seco da raiz em gramas para inoculação com diferentes fungos. Médias seguidas pela mesma letra não diferem entre si significativamente pelo teste de REGW ao nível de $5 \%$.

A altura média das plantas aos 21 dias gerou resultados que na análise conjunta dos dados não apresentaram interação entre os fatores fungos e fungicidas nem diferenças significativas para esses dois fatores. A média obtida entre todos os tratamentos foi de $8,0 \mathrm{~cm}$ e o coeficiente de variação foi de $37,46 \%$ conforme a Tabela 4 .

A altura das plantas, na época da colheita apresentou resultados na análise conjunta da variância que sugerem uma tendência no teste $F$ de diferença entre os fungicidas testados $(p=0,1088)$, sendo que nos trartamentos onde se utilizou Iprodione a 
altura das plantas foi superior. Não houve diferença significativa entre os fungos testados nem interação entre fungos $\mathrm{x}$ fungicidas. $\mathrm{A}$ altura média das plantas nessa época foi de $25,24 \mathrm{~cm}$ e o coeficiente de variação foi de $37,40 \%$.

Os resultados obtidos através da contagem de plantas vivas e plantas mortas semanalmente foram transformados em emergência $\left(n^{\circ}\right.$ de plantas emergidas 15 dias após plantio sobre $o \mathrm{n}^{\circ}$ total de sementes semeadas expresso em porcentagem) e sobrevivência (no. de plantas vivas na colheita, aproximadamente aos 60 dias após o plantio sobre o no. total de sementes semeadas expresso em porcentagem). Esses dois parâmetros estão apresentados na Tabela 5 .

Tabela 5. Resultados médios obtidos da emergência e sobrevivência nos experimentos de vasos com solo em casa-de-vegetação na Fase 2.

\begin{tabular}{|c|c|c|}
\hline Tratamento & \% emergência & \% sobrevivência \\
\hline FI & 90 & 72 \\
\hline $\mathrm{F} \varnothing$ & 83 & 65 \\
\hline FT & 85 & 73 \\
\hline OI & 95 & 89 \\
\hline$O \varnothing$ & 92 & 85 \\
\hline OT & 90 & 81 \\
\hline $\mathrm{RI}$ & 85 & 35 \\
\hline $\mathrm{R} \varnothing$ & 61 & 19 \\
\hline RT & 71 & 35 \\
\hline Média geral & 83,56 & 61,56 \\
\hline $\mathrm{CV} \%$ & 21,32 & 36,57 \\
\hline
\end{tabular}


onde: $\mathrm{F}=$ Fusarium, $\mathrm{R}=$ Rhizoctonia, $\mathrm{O}=$ Ausência de fungo. $\mathrm{I}=$ Iprodione, $\mathrm{T}=$ Thiram e $\varnothing=$ ausência de fungicida.

A emergência das plântulas de alfafa não foi influenciada pela interação dos fatores fungo $\mathrm{x}$ fungicida segundo a análise conjunta de variância. Entretanto os fatores fungo e fungicida diferiram significativamente com $p=0,0001$ e $p=0,0456$, respectivamente, para a \% de emergência. Assim após aplicação do teste de REGW para distinção de médias (SAS 1987), os tratamentos que foram inoculados com Fusarium e a testemunha não diferiram entre si mas foram superiores a inoculação com a Rhizoctonia, que depreciou a \% de emergência conforme a Figura 6 ao nivel de $5 \%$. Esse mesmo teste apontou diferença entre os fungicidas utilizados, sendo as \% de emergência favorecidas pelo uso dos fungicidas Iprodione e Thiram em relação à testemunha, como podem ser observadas na Figura 7. 


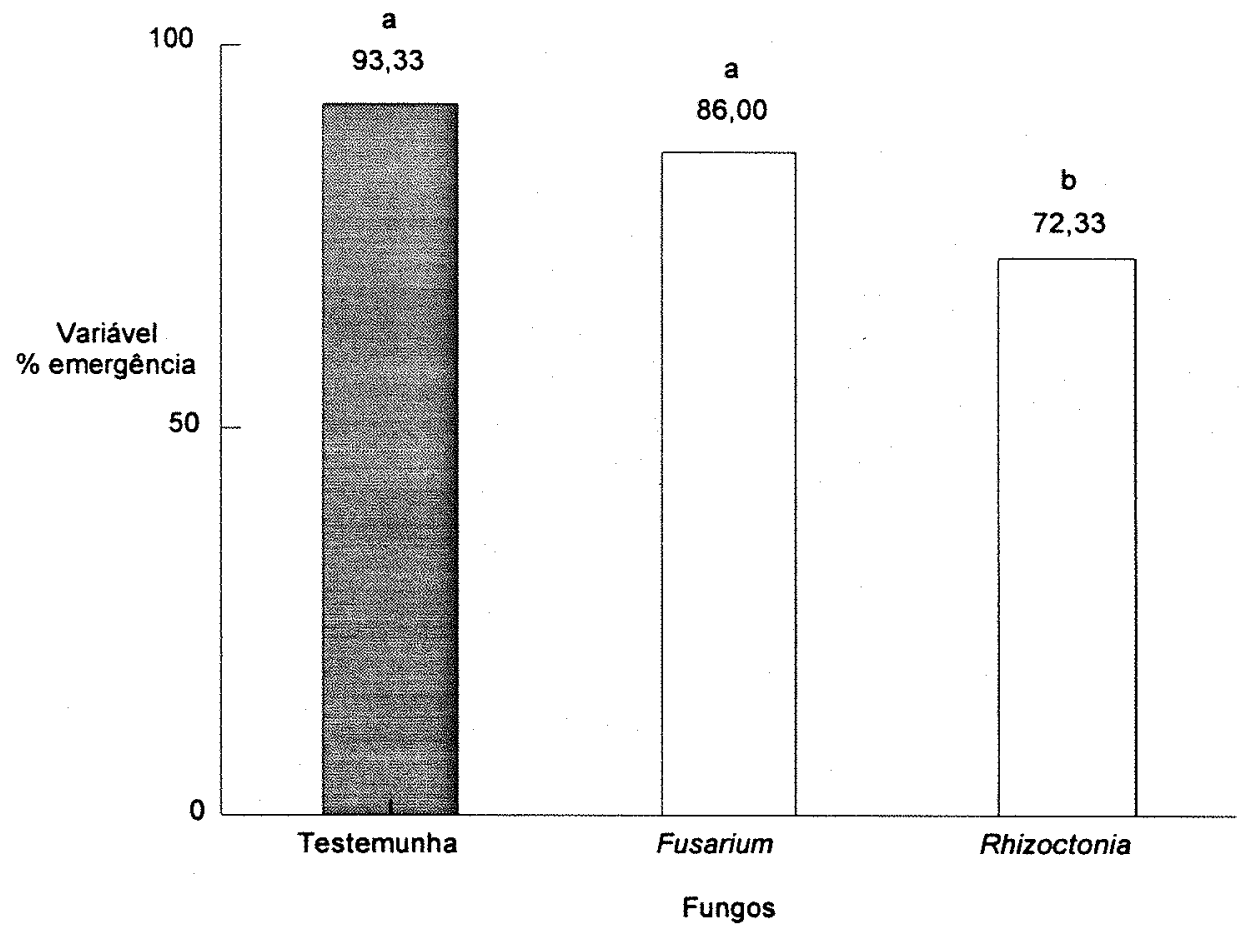

Figura 6. Porcentagem de emergência para inoculação com diferentes fungos. Médias seguidas pela mesma letra não diferem significativamente pelo teste de REGW ao nível de $5 \%$. 


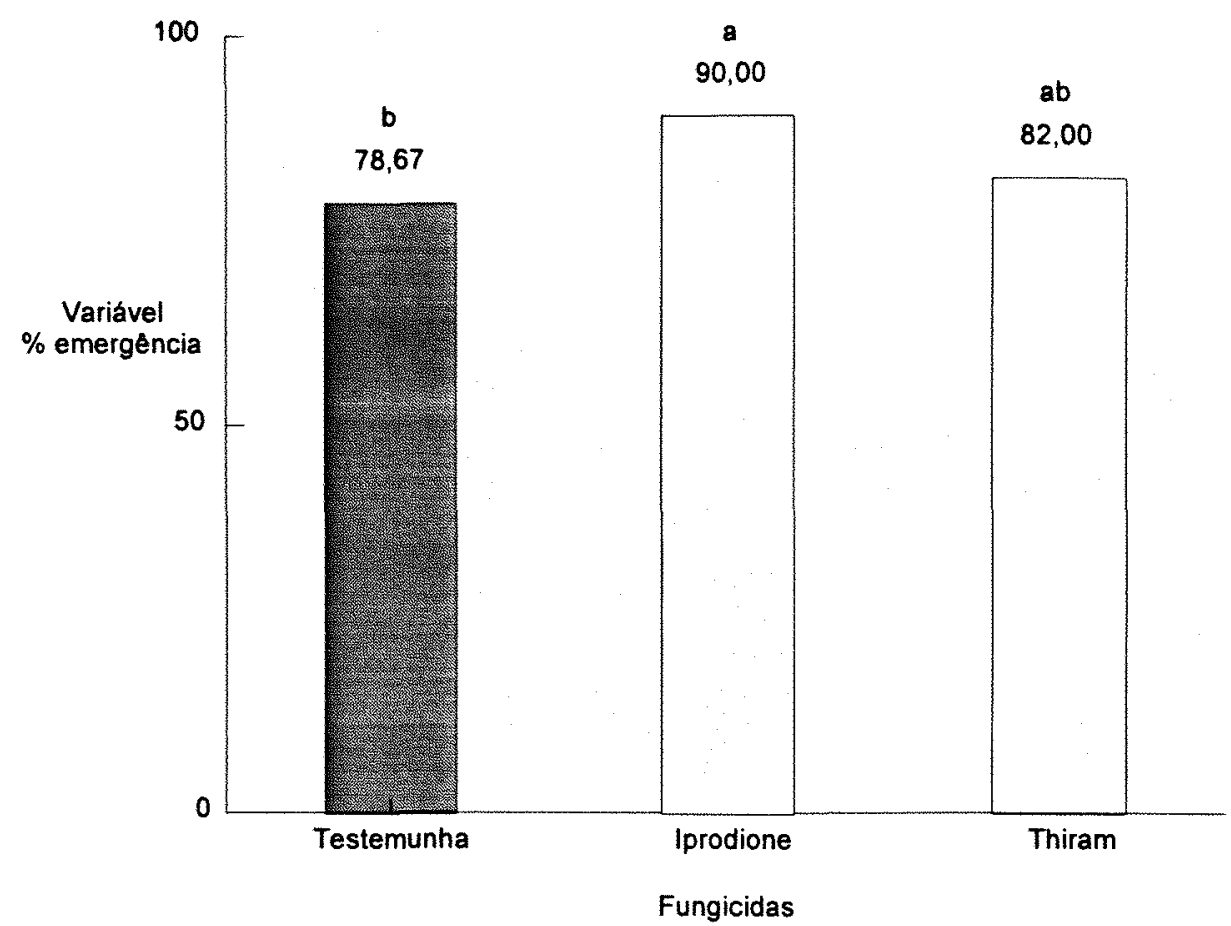

Figura 7. Porcentagem de emergência para uso de diferentes fungicidas no tratamento de sementes. Médias seguidas pela mesma letra não diferem significativamente pelo teste de REGW ao nível de $5 \%$.

$\mathrm{Na}$ análise conjunta da variância para sobrevivência não houve interação entre fungo $\mathrm{x}$ fungicida $\mathrm{e}$ efeito do fator fungicida enquanto que $\mathrm{o}$ fator fungo diferiu significativamente pelo teste $\mathrm{F}(\mathrm{p}=0,0001)$. Foi aplicado o teste de REGW ao nível de $5 \%$ e detectou-se que o tratamento com a Rhizoctonia foi o que mais depreciou a sobrevivência, seguido do Fusarium. A testemunha manteve a sobrevivência das plantas no decorrer do tempo, com média de $85 \%$, conforme mostra a Figura 8 . Apesar de não haver diferença estatística os fungicidas Iprodione e Thiram melhoraram a \% de sobrevivência da alfafa, uma vez que com o uso de fungicidas houve $35 \%$ de plantas 
sobreviventes contra apenas $19 \%$ no tratamento onde inoculou-se a Rhizoctonia e não se utilizou fungicidas.

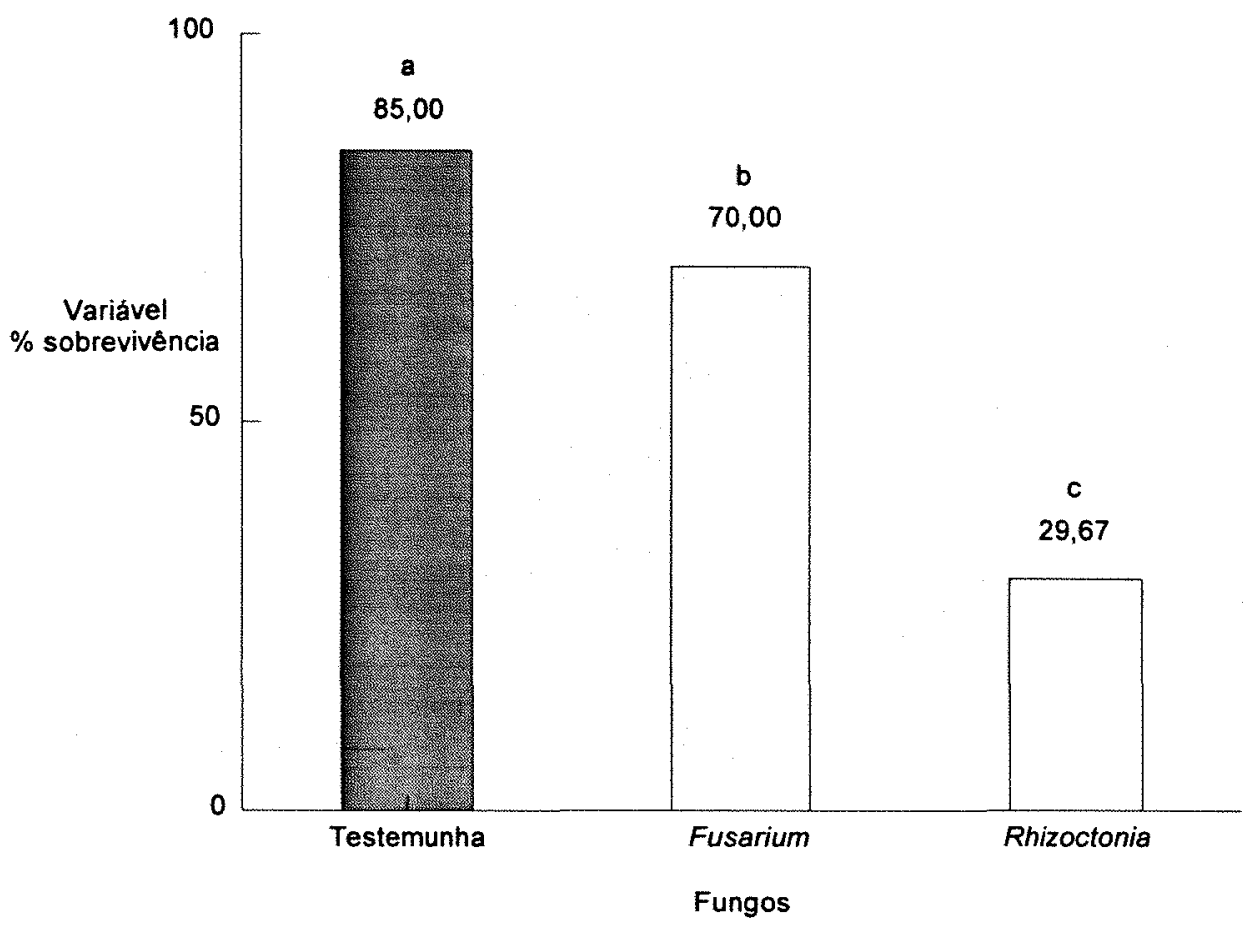

Figura 8. Porcentagem de sobrevivência para inoculação com diferentes fungos. Médias seguidas pela mesma letra não diferem significativamente pelo teste de REGW ao nível de $5 \%$.

A Figura 9 colocada abaixo nos permite observar semanalmente $o$ comportamento da morte das plântulas de alfafa por cada fungo. Nesta Figura é evidente a diferença entre os tratamentos onde a Rhizoctonia provocou os maiores prejuízos até a terceira semana havendo depois uma estabilização para os tratamentos com fungicida. Os tratamentos que receberam inoculação com Fusarium apresentavam também mortes 
até a terceira semana e depois mantiveram um comportamento estável independente do uso de fungicidas.

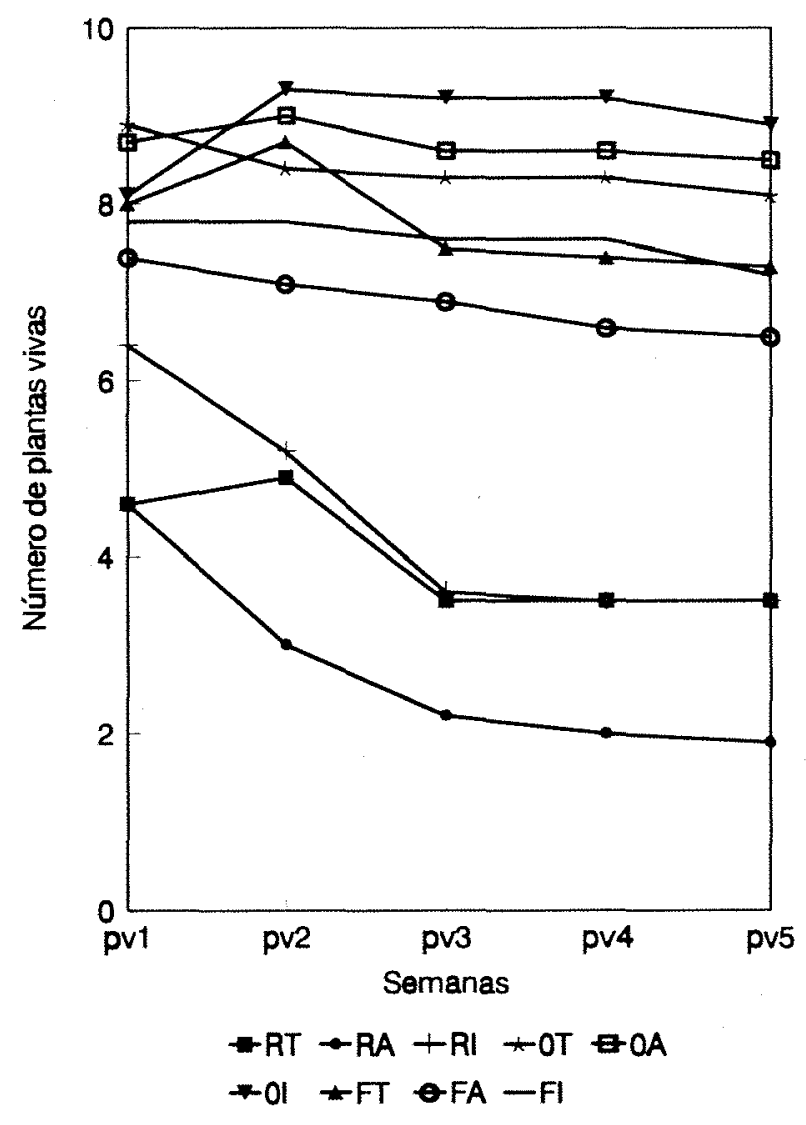

Figura 9. Número de plantas vivas (PV) na $1^{\mathrm{a}}, 2^{\mathrm{a}}, 3^{\mathrm{a}}, 4^{\mathrm{a}}$ e $5^{\mathrm{a}}$ semana para os tratamentos FI, FT, FA, RI, RT, RA, 0I, 0T, 0A.

onde:
$\mathrm{R}=$ Rhizoctonia
$I=$ Iprodione
$\mathrm{F}=$ Fusarium
0 = ausência fungo
$T=$ Thiram
$A=$ ausência fungicida 
Os resultados obtidos neste trabalho com o tratamento de sementes com fungicidas indicam a obtenção de controle dos patógenos empregados até a fase de emergência das plântulas, uma vez que estes não afetam os resultados de ps pa, ps raiz, e sobrevivência. Os resultados médios obtidos nos tratamentos com o uso de Iprodione que elevou a $\%$ de emergência para $90 \%$ e Thiram para $82 \%$ são suficientes para o controle dos patógenos até a idade de 15 dias das plântulas onde mediu-se a \% de emergência. Após essa fase o uso dos fungicidas não promoveu efeitos o que pode ser notado através dos outros parâmetros avaliados. Esses resultados confirmam as colocações de MYRES e RHODES (1989) quando comentam que os fungicidas Metalaxyl e Pyroxyfur em tratamento de semente diminuiram mas não eliminaram o efeito do patógeno Pythophthora sobre a alfafa. Pode-se inferir em relação a esses resultados que a aplicação de fungicida em superficie após esse período de 15 dias deverá apresentar efeito benéfico no controle dos efeitos causados pelos patógenos, pois no tratamento de semente o fungicida fica aderido a testa da semente, que no caso da alfafa é elevada do solo no processo de germinação e emergência, carregando consigo parte do fungicida que deveria permanecer no solo para o controle dos fungos.

Em relação ao ataque dos patógenos é evidente os efeitos mais drásticos da Rhizoctonia em relação ao Fusarium e a Testemunha em todos os parâmetros mensurados, o que coincide com os dados coletados por HANCOCK (1983) quando pesquisou as doenças de plântulas de alfafa na Califórnia.

Não houve diferença significativa na altura das plântulas, ao contrário do que foi encontrado por MYRES e RHODES (1989), denotando que o parâmetro representado pela altura da planta de alfafa aos 15 dias após emergência não é capaz de detectar o vigor das plântulas. Esse resultado talvez tenha sido influenciado pelo fato de que as plantas mortas foram retiradas dos vasos promovendo maior espaço para que as outras se 
desenvolvessem. Desse modo, as variáveis estudadas ALT 21 E ALT C obtidas de plantas individuais sofreram o efeito da retirada das plantas mortas favorecendo uma compensação do crescimento naquelas que conseguiram sobreviver, chegando a altura semelhante à testemunha, evidenciando crescimento normal das plantas individualmente, mas menor massa e altura total por parcela, que se entende aqui como unidade de área.

Os parâmetros mensurados no experimento em vasos de Leonard foram submetidos a análise da variância em esquema fatorial 4 fungicidas $\times 3$ estirpes de Rhizobium. O Teste $\mathrm{F}$ foi utilizado para determinar a significância de cada fator e a interação fungicida x estirpe Rhizobium do modelo.

O teste mais adequado foi utilizado para comparar a diferença entre as médias dos tratamentos para cada parâmetro mensurado.

Para avaliação do efeito desses fatores sobre a rizobiologia nas raízes foram medidos o peso-seco da raiz (ps raiz), número de nódulos ( $\mathrm{N}$ nod), o peso-seco dos nódulos (ps nod) e a atividade de redução do acetilleno. Os resultados obtidos neste trabalho são apresentados na Tabela 6. 
Tabela 6. Peso-seco das raízes por parcela, número de nódulos por parcela, peso-seco dos nódulos por parcela e atividade de redução de acetileno para o experimento em vaso de Leonard, estrutura fatorial fungicida x estirpe Rhizobium.

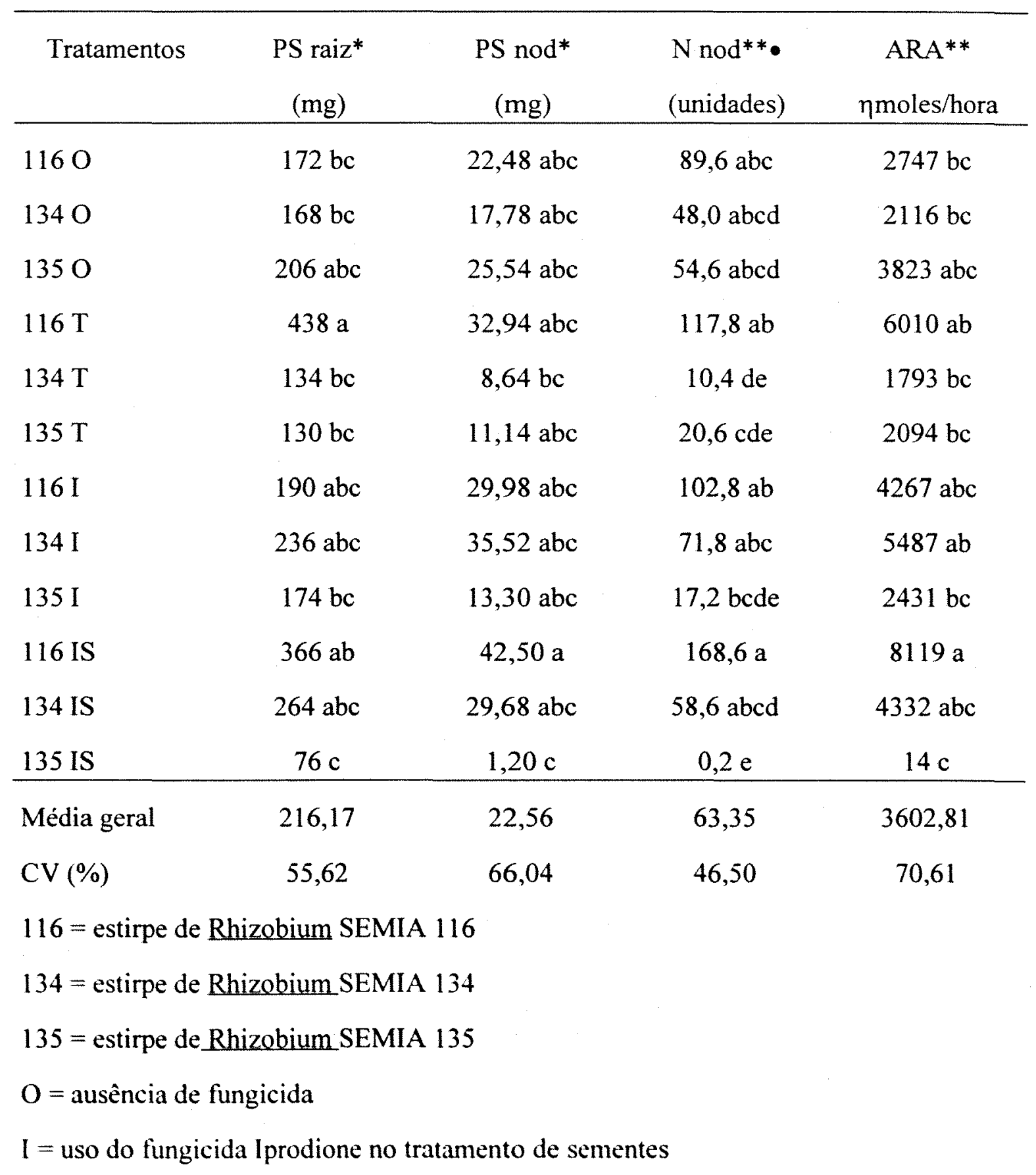


$\mathrm{T}=$ uso do fungicida Thiram no tratamento de sementes

IS = uso do fungicida Iprodione no tratamento de sementes associado com a aplicação em superfície do mesmo fungicida após uma semana da emergência das plântulas.

* utilizado o Teste de Tukey para diferenciação das médias (SAS 1987)

** utilizado o Teste de Ryan-Einot-Gabriel-Welsh para diferenciação das médias (SAS 1987)

*** médias seguidas pela mesma letra não diferem significativamente ao nível de $5 \%$

- para análise da variável usou-se a transformação $\sqrt{N N O D}+$ constante, sendo que apenas o CV refere-se aos dados transformados.

MONTEIRO et alli (1990) encontraram níveis de coeficiente de variação da ordem de $68,5 \%$ quando mediu as variáveis número de nódulos/planta e ARA.

O peso-seco da raíz foi uma variável em que houve interação entre a estirpe do Rhizobium e o tipo de fungicida utilizado no teste $F(p=0,0067)$. A partir desse resultado foi aplicado o teste de Tukey para diferenciação entre as médias dos tratamentos. Não houve grandes variações entre os tratamentos, mas dois tratamentos apresentaram dados extremos, a estirpe SEMIA 116 combinada com fungicida Thiram apresentou a produção mais alta de raizes $438 \mathrm{mg}$, e a estirpe SEMIA 135 na presença de Iprodione em superfície apresentou os resultados mais depressivos, $76 \mathrm{mg}$.

O peso-seco dos nódulos também possui interação entre estirpe de Rhizobium e fungicida, com $\mathrm{p}=0,0131$ no teste $\mathrm{F}$. Neste caso o pior resultado, $1,20 \mathrm{mg}$ de peso-seco de nódulos, também ficou para o tratamento SEMIA 135 com Iprodione em superfície, e o melhor resultado foi para a SEMIA 116 combinada com o fungicida Iprodione em superficie. Observa-se neste item que a SEMIA 116 não diferiu quanto ao peso-seco dos 
nódulos usando-se qualquer tipo de fungicida. Foi aplicado para diferenciação das médias o teste de Tukey (SAS, 1987).

O número de nódulos ( $\mathrm{N}$ nod) apresentou interação significativa entre estirpes de Rhizobium e fungicidas para o teste $\mathrm{F}$ de análise da variância com $\mathrm{p}=0,0034$. Foi aplicado o teste REGW (SAS 1987) para diferenciação das médias entre os tratamentos. Os tratamentos com a estirpe SEMIA 116 não sofreram alterações significativas dado ao uso dos fungicidas, havendo inclusive um favorecimento no $\mathrm{N}$ nod com o uso dos fungicidas. A estirpe 134 apresentou-se diferente da SEMIA 116 apenas quando associada com o fungicida Thiram, sendo sua associação com os outros fungicidas iguais aos tratamentos com a estirpe SEMIA 116 e o tratamento controle da SEMIA 135 e suas associações com Iprodione ou Thiram. $\mathrm{O}$ uso do fungicida Iprodione em superfície proporcionou os piores resultados quando associado com a estirpe SEMIA 135.

A atividade de redução do acetileno (ARA) também apresentou interação estirpe de Rhizobium e fungicidas no teste $\mathrm{F}$ com $\mathrm{p}=0,0184$. Foi aplicado o teste REGW (SAS 1987) para diferenciação das médias entre tratamentos. Neste caso também podese notar o efeito depressivo da combinação entre a estirpe 135 e o uso do fungicida Iprodione em superficie.

As três estirpes quando utilizadas sem uso de fungicidas não diferem entre si quanto a capacidade de inoculação e nodulação pois todas variáveis avaliadas na Tabela 6 não diferiram quando alterou-se as estirpes utilizadas.

Para avaliação do efeito desses fatores sobre a parte-aérea das plantas foi medido o peso-seco da parte-aérea (ps pa) a \% nitrogênio na parte-aérea $(\mathrm{N})$, a altura das plantas com 21 dias (H21) e a altura das plantas por ocasião da colheita (HC). Os resutados podem ser observados na Tabela 7. 
Tabela 7. Peso-seco da parte-aérea, altura das plantas aos 21 dias e altura das plantas por ocasião da colheita para o experimento em vasos de Leonard, estrutura fatorial fungicida x estipre Rhizobium.

\begin{tabular}{lccc}
\hline Tratamentos & $\begin{array}{c}\text { ps pa* } \\
(\mathrm{mg})\end{array}$ & $\begin{array}{c}\mathrm{H} 21^{* *} \\
(\mathrm{~cm})\end{array}$ & $\begin{array}{c}\mathrm{H} \mathrm{C} * \\
(\mathrm{~cm})\end{array}$ \\
\hline $116 \mathrm{O}$ & $270 \mathrm{abc}$ & $2,86 \mathrm{abc}$ & $17,99 \mathrm{abc}$ \\
$134 \mathrm{O}$ & $202 \mathrm{bc}$ & $4,16 \mathrm{a}$ & $17,00 \mathrm{abc}$ \\
$135 \mathrm{O}$ & $220 \mathrm{abc}$ & $2,75 \mathrm{abc}$ & $19,47 \mathrm{abc}$ \\
$116 \mathrm{~T}$ & $558 \mathrm{a}$ & $3,19 \mathrm{abc}$ & $31,47 \mathrm{a}$ \\
$134 \mathrm{~T}$ & $246 \mathrm{abc}$ & $2,14 \mathrm{bc}$ & $17,120 \mathrm{abc}$ \\
$135 \mathrm{~T}$ & $186 \mathrm{bc}$ & $2,49 \mathrm{bc}$ & $14,85 \mathrm{bc}$ \\
$116 \mathrm{I}$ & $222 \mathrm{abc}$ & $2,76 \mathrm{abc}$ & $19,79 \mathrm{abc}$ \\
$134 \mathrm{I}$ & $330 \mathrm{abc}$ & $3,65 \mathrm{ab}$ & $22,20 \mathrm{abc}$ \\
$135 \mathrm{I}$ & $198 \mathrm{bc}$ & $3,10 \mathrm{abc}$ & $16,85 \mathrm{abc}$ \\
116 IS & $472 \mathrm{ab}$ & $2,71 \mathrm{abc}$ & $25,72 \mathrm{ab}$ \\
134 IS & $364 \mathrm{ab}$ & $1,93 \mathrm{c}$ & $25,69 \mathrm{ab}$ \\
135 IS & $60 \mathrm{c}$ & $3,33 \mathrm{abc}$ & $8,70 \mathrm{c}$ \\
\hline Média geral & 277,33 & 2,92 & 19,74 \\
CV (\%) & 30,61 & 25,34 & 34,31 \\
\hline
\end{tabular}

* foi utilizada a transformação da variável para raiz quadrada do PSPA + constante e aplicou-se o teste de REGW para diferenciação ds médias.

** foi aplicado o teste de Tukey para diferenciação das médias.

*** médias seguidas pela mesma letra não diferem entre si significativamente ao nivel de $5 \%$. 
O peso-seco da parte-aérea apresentou comportamento interativo entre as estirpes e os fungicidas utilizados; através da aplicação do teste $F$ para análise da variância obteve-se um valor de $p=0,0090$. Foi aplicado o teste de REGW para diferenciação das médias. Os resultados apontam que para os tratamentos controle não houve diferença entre a estirpe utilizada. Quando usou-se o fungicida Thiram a estirpe SEMIA 116 foi superior a SEMIA 135 mas não diferiu da SEMIA 134. Para o fungicida Iprodione as três estirpes apresentaram o mesmo comportamento quando este foi utilizado no tratamento de sementes; entretanto quando utilizou-se este fungicida também em superfícide houve uma clara superioridade das estirpes SEMIA 116 e SEMIA 134 em relação a SEMIA 135.

Para a altura aos 21 dias (H21) houve interação entre fungo e fungicida no teste F da análise de variância com $p=0,0006$. Essa variável que está relacionada com o vigor da plântula apresenta diferença siginificativas (teste de Tukey) para os tratamentos com a SEMIA 134. O tratamento controle foi superior aos tratamentos com Thiram e Iprodione em superfície, sendo que o tratamento SEMIA 134 + Iprodione no tratamento de semente foi igual ao tratamento controle e igual ao tratamento com Thiram.

A altura das plantas por ocasião da colheita $(\mathrm{HC})$ também apresentou interação significativa entre os fatores fungo $\mathrm{x}$ fungicida, com $\mathrm{p}=00229$. Foi aplicado $\mathrm{o}$ teste de Tukey para diferenciação entre as médias, havendo superioridadee da estirpe 116 combinada com o fungicida Thiram em relação aos tratamentos 135T e 135IS. Quando aplicou-se o fungicida Iprodione em superficie houve superioridade significativa das estirpes SEMIA 116 e SEMIA 134 em relação a estipre SEMIA 135, assim como ocorreu para o ps pa. 
A Tabela 8 apresenta os resultados da porcentagem de nitrogênio da parte-aérea das plantas.

Tabela 8. Resultados médios obtidos da porcentagem de $\mathrm{N}$ da parte-aérea das plantas por ocasião da colheita.

\begin{tabular}{cc}
\hline Tratamentos & $\mathrm{N} \%$ \\
\hline $116 \mathrm{O}$ & 2,45 \\
$116 \mathrm{~T}$ & 3,05 \\
$116 \mathrm{I}$ & 2,74 \\
$116 \mathrm{IS}$ & 2,83 \\
$134 \mathrm{O}$ & 2,54 \\
$134 \mathrm{~T}$ & 2,55 \\
$134 \mathrm{I}$ & 2,45 \\
$134 \mathrm{IS}$ & 2,86 \\
$135 \mathrm{O}$ & 2,33 \\
$135 \mathrm{~T}$ & 2,51 \\
$135 \mathrm{I}$ & 2,24 \\
$135 \mathrm{IS}$ & 2,42 \\
\hline Média geral & 2,58 \\
CV $\%)$ & 15,9 \\
\hline
\end{tabular}

A análise de variância dos fatores envolvidos com a variável $\mathrm{N} \%$ não mostrou interação entre as estirpes de Rhizobium utilizadas e os fungicidas empregados. Entretanto houve diferença significativa entre as diferentes estirpes utilizadas detectadas através do teste $\mathrm{F}$ com $\mathrm{p}=0,0155$. Posteriormente foi realizado o teste REGW para se detectar a diferenciação entre as estipres, conforme mostra a Tabela 9. 
Tabela 9. Comparações múltiplas para o efeito principal da estirpe de Rhizobium sobre a variável porcentagem de nitrogênio.

\begin{tabular}{|c|c|}
\hline Estirpe & Média dos tratamentos* \\
\hline SEMIIA 116 & $2,767 \mathrm{a}$ \\
\hline SEMIA 134 & $2,600 \mathrm{ab}$ \\
\hline SEMIA 135 & $2,375 b$ \\
\hline
\end{tabular}

*médias seguidas pela mesma letra não diferem significativamente entre si ao nível de $5 \%$ através do uso do teste REGW.

Dessa forma podemos observar que houve uma superioridade dos tratamentos que utilizaram a inoculação com a SEMIA 116 em relação a SEMIA 135, independente do fungicida utilizado, e que não houve diferença entre as estipes SEMIA 116 e SEMIA 134 e entre as SEMIA 134 e SEMIA 135. Houve, portanto, uma diferença entre as SEMIAS 116 e 135.

Os resultados obtidos neste experimento confirmam as conclusões obtidas por BACKMAN (1978) MONTEIRO et alli (1990) e ODEYEMI \& ALEXANDER (1992) que relatam haver um interação entre estipres de Rhizobium e utilização de fungicidas de maneria geral. Estes últimos autores trabalhavam com alfafa e isolaram inclusive estirpes de Rhizobium meliloti resistentes ao Thiram. MATENSON (1992) não encontrou essa interação, quando trabalhou com isolados diferentes de Rhizobium meliloti provenientes de solos com ou sem manejo químico. De forma geral, neste trabalho, a SEMIA 116 apresentou os melhores resultados quando usou-se os fungicidas, podendo-se evidenciar 
esse fato quando observa-se a quantidade total de $\mathrm{N}$ colocada no sistema, uma vez que essa só dependeu da fixação biológica de N, pois trabalhou-se com solução nutritiva sem adição de nitrogênio, (Tabela 10). A quantidade de $\mathrm{N}$ colocada no sistema pela SEMIA 116 é $267,25 \%$ maior que aquela colocada pela SEMIA 135 .

Tabela 10. Quantidade de $\mathrm{N}$ total fixada pela alfafa em função das estirpes utilizadas por ocasião da colheita da alfafa com 60 dias do plantio.

\begin{tabular}{rccc}
\hline Estirpe & $\% \mathrm{~N}$ & PSPA $(\mathrm{mg})^{*}$ & $\mathrm{mg} \mathrm{N}$ \\
\hline SEMIA 116 & 2,767 & 380,5 & 10,53 \\
SEMIA 134 & 2,600 & 285,5 & 7,42 \\
SEMIA 135 & 2,375 & 166,0 & 3,94 \\
\hline
\end{tabular}

* médias dos tratamentos que utilizaram a mesma estirpe.

Outro fator que interfere na fixação de nitrogêncio é a dose de fungicida empregada, pois dependendo da dose e da reação da estirpe utilizada ocorre interações quanto ao nitrogênio, YSOI e YOSHIDA (1988); RENNIER (1985); TU (1981) e ODEYEMI \& ALEXANDER (1992).

Neste trabalho utilizou-se três dosagens de fungicida por grama de semente, ou seja: $2 \mathrm{mg}$ de Rovral (1 mg p.a. de Iprodine), $6 \mathrm{mg}$ de Rhodiauram (4,2 mg p.a. de Thiram) e $75 \mathrm{mg}$ de Rovral em superficie ( $37,5 \mathrm{mg}$ p.a. de Iprodione), este último foi calculado considerando-se a dose de Rovral aplicada em superficie e uma taxa de semeadura de $20 \mathrm{Kg} / \mathrm{ha}$. A dosagem de $37,5 \mathrm{mg}$ de Iprodione teve efeito evidentemente depressivo no número de nódulos quando aplicado em superficie e associado a SEMIA 135 (Tabela 6). 
Por outro lado, as estirpes SEMIA 116 e 134 não foram afetadas quanto ao peso-seco da raiz, peso-seco dos nódulos, número de nódulos e ARA (Tabela 6). A estirpe SEMIA 116 apresenta tendência de melhor resistência ao uso dos fungicidas testados. TU (1981) encontrou inibição do processo de infecção, nodulação e fixação de nitrogênio quando trabalhou com doses de fungicida da ordem de 2,5 a $3,0 \mathrm{mg}$ de Thiram/g de semente e estímulo do processo quando trabalhou com doses entre 0,2 e 0,5 mg de Thiram/g de semente. ODEYEMI \& ALEXANDER (1992) também encontraram estirpes de Rhizobium meliloti resistentes ao uso de Thiram em dose semelhante a desse trabalho, ou seja, de $5 \mathrm{mg}$ de Thiram/g de semente.

\subsection{Fase 3 - Experimento a campo com o objetivo de estudar várias taxas de semeadura e os efeitos do tratamento de sementes com fungicidas.}

Os resultados obtidos neste experimento para as variáveis peso-seco da raiz, peso-seco da parte-aérea, altura aos 21 dias e porcentagem de nitrogênio são apresentados na Tabela 11. Para proceder a análise estatística desses dados foi necessário a aplicação de transformações dessas variáveis. Assim o peso-seco da raiz (ps raiz) foi transformado para $\sqrt{\text { psraiz }}+$ constante, o peso-seco da parte-aérea (ps pa) foi transformado em $\sqrt{p s p a}+$ constante, a porcentagem de nitrogênio foi transformada na sua recíproca $1 / \mathrm{N}$ e a altura aos 21 dias (A21) foi transformada em $\sqrt{A 21}+$ constante. Após essas transformações foi aplicada a técnica do uso de contrastes através do comando CONTRAST do Proc GLM (SAS, 1987) e formação de contrastes específicos de interesse. 
Tabela 11. Resultados médios obtidos no experimento a campo com diversas taxas de semeadura e diferentes fungicidas no tratamento de sementes para as variáveis p.s. raiz (g), p.s.p.a. (g), altura aos 21 dias (cm) e porcentagem de nitrogênio.

\begin{tabular}{|c|c|c|c|c|}
\hline Tratamentos (1) & p.s.p.a. & p.s. raiz. & $\mathrm{N} \%$ & A 21 \\
\hline $5 \varnothing$ & 15,22 & 1,49 & 5,07 & 3,52 \\
\hline $5 \mathrm{I}$ & 19,23 & 2,78 & 3,66 & 3,46 \\
\hline $5 \mathrm{~T}$ & 7,05 & 1,50 & 3,38 & 2,85 \\
\hline $8 \varnothing$ & 14,88 & 2,40 & 3,44 & 4,17 \\
\hline $8 \mathrm{I}$ & 24,53 & 4,13 & 3,84 & 2,87 \\
\hline $8 \mathrm{~T}$ & 16,88 & 1,70 & 5,28 & $3,60 q$ \\
\hline $10 \varnothing$ & 27,15 & 4,25 & 4,56 & 4,68 \\
\hline $10 \mathrm{I}$ & 22,29 & 2,74 & 5,40 & 3,88 \\
\hline $10 \mathrm{~T}$ & 17,33 & 2,61 & 4,93 & 5,08 \\
\hline $15 \varnothing$ & 34,83 & 5,79 & 4,48 & 5,49 \\
\hline $15 \mathrm{I}$ & 29,64 & 5,29 & 4,92 & 4,06 \\
\hline $15 \mathrm{~T}$ & 25,78 & 4,60 & 5,94 & 4,23 \\
\hline $20 \varnothing$ & 24,76 & 4,15 & 4,52 & 4,52 \\
\hline $20 \mathrm{I}$ & 21,13 & 3,45 & 4,78 & 4,06 \\
\hline $20 \mathrm{~T}$ & 42,22 & 7,71 & 4,38 & 4,49 \\
\hline $25 \varnothing$ & 31,33 & 5,72 & 4,30 & 4,08 \\
\hline $25 \mathrm{I}$ & 37,67 & 6,68 & 4,61 & 4,73 \\
\hline $25 \mathrm{~T}$ & 41,20 & 8,07 & 4,40 & 4.61 \\
\hline * média geral & 25,17 & 4,17 & 4,55 & 4.13 \\
\hline$* \operatorname{CV}(\%)$ & 43,74 & 47,11 & 11,71 & 26,03 \\
\hline
\end{tabular}


onde : $\quad \varnothing$ =ausência de $\quad \mathrm{I}=$ Iprodione $\quad \mathrm{T}=$ Thiram

fungicida

* o coeficiente de variação é relativo aos dados transformados enquanto as médias obtidas em cada tratamento e a geral refere-se aos dados originais onde: o número referese a taxa de semeadura/ha e os tratamentos $\varnothing$ trata-se do controle, I do Iprodione e T do Thiram.

(1) os números referem-se às taxas de semeadura por hectare .

A Tabela 12 mostra os contrastes de interesse obtidos nesta análise e seu nível de significância através de utilização do teste F.

Tabela 12. Contrastes de interesse para as variáveis transformadas, valor do número e sua significância.

\begin{tabular}{lcccc}
\hline & p.s. p.a. & p.s. raiz & A 21 & N\% \\
\cline { 2 - 5 } Contraste(1) & valor p & valor p & valor p & valor p \\
\hline 10 versus 15 & 0,3642 & 0,2059 & 0,9251 & 0,8163 \\
15 versus 20 & 0,9545 & 0,9529 & 0,7027 & 0,1319 \\
20 versus 25 & 0,4927 & 0,3350 & 0,8994 & 0,5634 \\
25 versus 5 & $0,0022^{* *}$ & $0,0007^{* *}$ & $0,0492^{*}$ & 0,1157 \\
5 versus 8 & 0,4316 & 0,5490 & 0,4728 & 0,4178 \\
dentro 10 & 0,8144 & 0,5681 & 0,4324 & 0,0817 \\
dentro 15 & 0,9591 & 0,9665 & 0,5393 & 0,8574 \\
dentro 20 & 0,3696 & 0,2931 & 0,7561 & 0,2772 \\
dentro 25 & 0,8763 & 0,9290 & 0,7099 & 0,3550 \\
dentro 5 & 0,4712 & 0,5271 & 0,8799 & 0,6569 \\
dentro 8 & 0,7076 & 0,4136 & 0,1169 & 0,6226 \\
\hline
\end{tabular}


(1) os números referem-se às taxas de sememadura por hectare.

valores seguidos de ${ }^{* *}$ são contrastes que possuem diferença estatística significativa ao nível de $1 \%$ e ${ }^{*}$ possuem essa diferença ao nível de $5 \%$.

As variáveis ps pa, ps raiz e altura aos 21 dias apresentaram diferenças significativas apenas no contraste da taxa de semeadura de $5 \mathrm{Kg}$ de sementes/ha contra a taxa mais elevada de $25 \mathrm{Kg}$ de sementes/ha. A partir de $8 \mathrm{Kg} / \mathrm{ha}$ as taxas de semeadura não diferem entre si, uma vez que as taxas de 25,20,15 e 10 não apresentaram diferença entre si pelos contrastes estabelecidos e a taxa de $8 \mathrm{Kg} / \mathrm{ha}$ é significativamente igual a taxa de $5 \mathrm{Kg} / \mathrm{ha}$ e esta difere da taxa de $25 \mathrm{Kg} / \mathrm{ha}$. Os contrastes montados para estabelecer as diferenças entre o uso de fungicidas (sem uso de fungicidas com uso de Thiram ou com uso de Iprodione) dentro de cada nivel do fator taxa de semeadura não apresentaram diferenças para as variáveis acima.

A variável porcentagem de nitrogênio não apresentou nenhum contraste que definisse diferença entre os tratamentos. Esse resultado era esperado uma vez que o solo apresentava problemas quanto aos níveis de $\mathrm{N}$ mineral que impediram o funcionamento do processo de fixação de nitrogênio atmosférico. Portanto, se não houve nodulação, todas as plantas tiveram as mesmas possibilidades de absorção de nitrogênio do solo e não apresentaram diferença entre si.

Para as variáveis plantas vivas aos 7 dias (PV7), plantas vivas aos 14 dias (PV14), plantas vivas aos 48 dias (PV48), plantas mortas aos 7 dias (PM7) e plantas mortas aos 14 dias (PM14) foi utilizado a análise de medidas repetidas no tempo. Esse tipo de análise pode ser utilizado quando várias medidas são tomadas no tempo numa mesma unidade experimental, onde as medidas tendem a estar correlacionadas umas com as outras. 
O estudo sobre o efeito dos tratamentos no tempo, considerando as avaliações efetuadas para o número de plantas vivas aos 7,14 e 48 dias após emergência demonstram efeito significativo na análise multivariada para a interação tempo $x$ tratamento, usando teste de Wilk's Lambda.

Em consequência dessa interação significativa apontada através da análise multivariada foi realizada uma análise individual para cada variável usando-se contrastes (Tabela 13). 
Tabela 13. Resultados médios obtidos para PV7, PV14 e PV48 do experimento a campo com estrutura fatorial, com 6 taxas de semeadura e 3 usos de fungicidas.

\begin{tabular}{|c|c|c|c|}
\hline Tratamento(1) & PV 7 & PV 14 & PV 48 \\
\hline $5 \varnothing$ & 6,00 & 5,50 & 2,50 \\
\hline $5 \mathrm{I}$ & 11,75 & 9,00 & 4,75 \\
\hline $5 \mathrm{~T}$ & 7,50 & 7,50 & 2,25 \\
\hline $8 \varnothing$ & 12,25 & 11,50 & 2,75 \\
\hline $8 \mathrm{I}$ & 16,25 & 12,00 & 8,00 \\
\hline $8 \mathrm{~T}$ & 11,25 & 7,50 & 4,25 \\
\hline $10 \varnothing$ & 10,00 & 11,25 & 6,75 \\
\hline $10 \mathrm{I}$ & 15,00 & 13,00 & 7,50 \\
\hline $10 \mathrm{~T}$ & 21,50 & 15,25 & 5,00 \\
\hline $15 \varnothing$ & 26,25 & 26,00 & 11,00 \\
\hline $15 \mathrm{I}$ & 19,25 & 17,75 & 9,75 \\
\hline $15 \mathrm{~T}$ & 27.75 & 26,67 & 9,25 \\
\hline $20 \varnothing$ & 29,75 & 27,75 & 8,50 \\
\hline $20 \mathrm{I}$ & 28,25 & 23,75 & 7,75 \\
\hline $20 \mathrm{~T}$ & 41,75 & 41,33 & 13,00 \\
\hline $25 \varnothing$ & 35,00 & 32,67 & 9,50 \\
\hline $25 \mathrm{I}$ & 34,75 & 33,67 & 14,25 \\
\hline $25 \mathrm{~T}$ & 54,50 & 36,25 & 16,25 \\
\hline Média geral & 22,71 & 19,10 & 7,94 \\
\hline CV $(\%)$ & 69,43 & 77,70 & $49,25^{*}$ \\
\hline
\end{tabular}


* os dados seguidos de asteriscos refere-se aos dados transformados, no caso foi utilizado a $\sqrt{P V 48}$, os outros dados restantes são originais.

(1) os números na coluna referente aos tratamentos representam as taxas de semeadura, $\varnothing$ é a Testemunha, I é o Iprodione e T o Thiram.

Os contrastes de interesse para as variáveis PV7, PV14 e PV48 são apresentados na Tabela 14 .

Tabela 14. Valores de p no teste F para contrastes de interesse para as variáveis PV7, PV14 e PV48 do esperimento a campo com estrutura fatorial (uso de fungicidas * taxas de semeadura).

\begin{tabular}{lccc}
\hline \multicolumn{1}{c}{ Contraste } & PV 7 & PV 14 & PV 48 \\
\hline 10 versus 15 & 0,2236 & 0,1048 & 0,2476 \\
15 versus 20 & 0,9318 & 0,2353 & 0,8703 \\
20 versus 25 & 0,2236 & 0,6781 & 0,2930 \\
25 versus 5 & $0,0010^{* *}$ & $0,0001^{* *}$ & $0,0004^{* *}$ \\
5 versus 8 & 0,5313 & 0,6229 & 0,4793 \\
dentro do 10 & 0,7111 & 0,9782 & 0,7963 \\
dentro do 15 & 0,9318 & 0,3638 & 0,9763 \\
dentro do 20 & 0,4948 & 0,2388 & 0,3536 \\
dentro do 25 & 0,7539 & 0,8217 & 0,7334 \\
dentro do 5 & 0,5885 & 0,7845 & 0,5180 \\
dentro do 8 & 0,3072 & 0,7845 & 0,4238 \\
\hline
\end{tabular}

As taxas de semeadura quando avaliadas pelo número de plantas vivas (PV7, 14 e 48) não foram diferentes quando eram efetuadas a partir de $10 \mathrm{Kg} / \mathrm{ha}$. Não foi 
evidenciado o efeito do uso de fungicidas, uma vez todos os constrastes dento dos niveis de taxa de semeadura determinado não foram significativos.

Tabela 15. Número médio de plantas por $\mathrm{m}^{2}$ aos 7,14 e 48 dias após emergência do experimento a campo com estrutura fatorial (taxas de semeadura * fungicidas).

\begin{tabular}{lccc}
\hline \multirow{2}{*}{ Tratamento } & \multicolumn{3}{c}{ Número de plantas $/ \mathrm{m}^{2}$} \\
\cline { 2 - 4 } $5 \varnothing$ & 7 dias & 14 dias & 48 dias \\
\hline $5 \mathrm{I}$ & 7,50 & 6,88 & 3,13 \\
$5 \mathrm{~T}$ & 14,69 & 11,25 & 5,94 \\
$8 \varnothing$ & 9,38 & 9,38 & 2,81 \\
$8 \mathrm{I}$ & 15,31 & 14,38 & 3,44 \\
$8 \mathrm{~T}$ & 20,31 & 15,00 & 10,00 \\
$10 \varnothing$ & 14,06 & 9,38 & 5,31 \\
$10 \mathrm{I}$ & 12,50 & 14,06 & 8,44 \\
$10 \mathrm{~T}$ & 18,75 & 16,25 & 9,38 \\
$15 \varnothing$ & 26,88 & 19,06 & 6,25 \\
$15 \mathrm{I}$ & 32,81 & 32,50 & 13,75 \\
$15 \mathrm{~T}$ & 24,06 & 22,19 & 12,19 \\
$20 \varnothing$ & 34,69 & 33,34 & 11,56 \\
$20 \mathrm{I}$ & 37,19 & 34,69 & 10,62 \\
$20 \mathrm{~T}$ & 35,31 & 29,69 & 9,69 \\
$25 \varnothing$ & 52,19 & 51,66 & 16,25 \\
$25 \mathrm{I}$ & 43,75 & 40,84 & 11,88 \\
$25 \mathrm{~T}$ & 43,44 & 42,09 & 17,81 \\
\hline & 68,12 & 45,31 & 20,31 \\
\hline
\end{tabular}


Um resumo desses dados é apresentado na Figura 10 para que possa comparar as diferentes taxas de semeaduras.

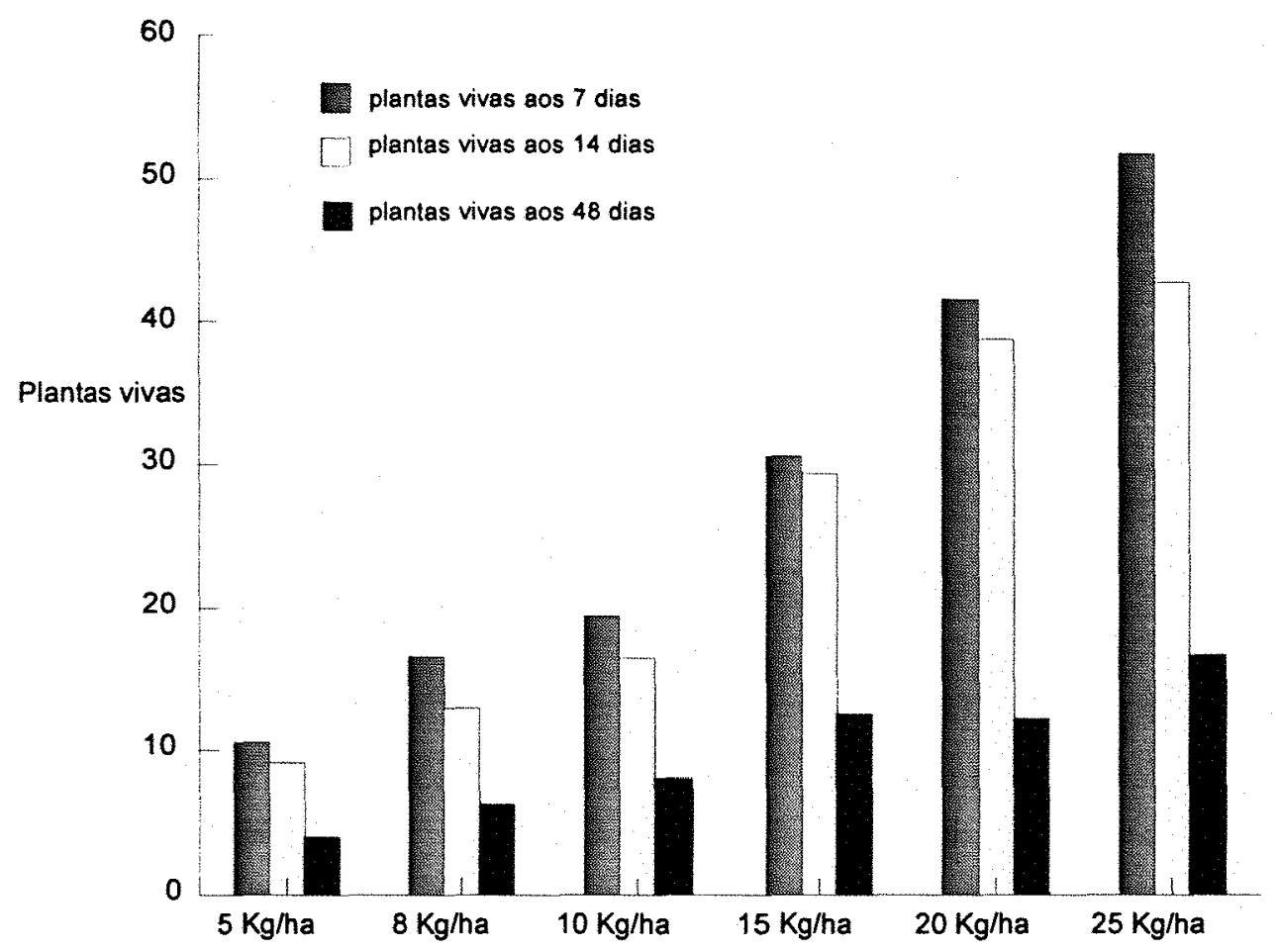

Figura 10. Número médio de plantas vivas por $\mathrm{m}^{2}$ aos 7,14 e 48 dias após a emergência por níveis do fator de semeadura do experimento a campo com estrutura fatorial (taxa de semeadura * fungicida).

Observando-se a figura acima e sabendo-se que um grama da semente utilizada possui aproximadamente 412 sementes, temos taxas de sobrevivências diferentes para cada taxa de semeadura conforme mostra a Tabela 16. 
Tabela 16. Taxas de sobrevivência (no. de plantas vivas aos 48 dias/no. de sementes utilizadas por $\mathrm{m}^{2}$ ) para as diferentes taxas de semeadura do experimento a campo com estrutura fatorial (taxa de semeadura* fungicida).

\begin{tabular}{cc}
\hline Taxa de semeadura $(\mathrm{Kg} / \mathrm{ha})$ & \% sobrevivência \\
\hline 5 & 1,92 \\
8 & 1,90 \\
10 & 1,95 \\
15 & 2,02 \\
20 & 1,48 \\
25 & 1,62 \\
\hline
\end{tabular}

Os resultados obtidos nesse experimento mostram que as taxas de semeadura acima de $10 \mathrm{Kg} / \mathrm{ha}$ não promoveram aumentos siginificativos no número de plantas por metro quadrado quer aos 7, 14 ou 48 dias após a emergência, no p.s.p.a., no p.s.raiz e na altura das plantas (Tabela 13). Esses dados coincidem com os resultados obtidos por outros autores, como na revisão de TESAR e JACKCOBS (1972) que em Michigam não obtiveram resultados positivos em doses superiores a $9 \mathrm{Kg} / \mathrm{ha}$, como para VAN KEUREN (1973) que não obteve incrementos em doses superiores a $13,4 \mathrm{Kg} / \mathrm{ha}$ e KEPLIN \& SANTOS (1991) que não detectaram diferenças entre taxas de semeadura de 5 a $15 \mathrm{Kg} / \mathrm{ha}$ no Rio Grande do Sul - Brasil.

$\mathrm{O}$ número de plantas médio por $\mathrm{m}^{2}$ neste trabalho, variou de 8 a 16 plantas $/ \mathrm{m}^{2}$, quando a taxa de semeadura foi de 10 a $25 \mathrm{Kg} /$ ha. Esse número é bastante inferior ao número recomendado por diversos autores para obtenção de elevada produtividade de matéria-seca/ha. Apenas alguns autores admitem que número de plantas $/ \mathrm{m}^{2}$ semelhante a 
esse possam produzir quantidades satisfatórias, de matéria-seca, como o caso de Triplett (1977) que trabalhou com controle de ervas daninhas em alfafa e concluiu que 10 a 20 plantas $/ \mathrm{m}^{2}$ apresentaram stands com produção satisfatória de matéria-seca/ha.

A porcentagem de sobrevivência indica claramente, que houve efeito drástico dos patógenos sobre o stand da alfafa. TESAR \& JACKCOBS (1972) relatam que a sobrevivência de 40 a $50 \%$ é apropriada para alfafa no primeiro ano. Os dados desse experimento estão ao redor de 1,5 a $2 \%$ independente da taxa de semeadura utilizada (Tabela 17), quando na área do campo experimental houve inoculação da Rhizoctonia e do Fusarium. Também MYRES e RHODES (1989) encontraram \% de emergência em solos infestados com Phytophtora de 5,5\% e HANCKOK (1983) encontrou \% de sobrevivência de 4,1 \% para solos infestados com Rhizoctonia. 


\section{CONCLUSÕES}

Os fungos isolados como causadores de damping-off em alfafa foram Rhizoctonia solani e Fusarium sp. Entretanto deve-se dar ênfase a época do ano em que se fez a coleta de amostras, uma vez que é provável que a temperatura do ambiente afete a presença de outros patógenos causadores de damping-off na cultura. Desse modo estudo sobre uso de fungicidas e tratamentos para o controle de damping-off devem ser especificados quanto a época do ano, local e ambiente (temperatura e umidade) da coleta de amostras.

O efeito do tratamento de semente de alfafa não incrementou os resultados finais avaliados através do peso seco da parte aérea, peso-seco da raiz e sobrevivência para qualquer dos dois fungicidas testados (Iprodione e Thiram). $\mathrm{O}$ fungicida Iprodione apresentou um efeito benéfico inicial aumentando a porcentagem de emergência das plantas mas não foi suficiente para manter esses resultados nos parâmetros finais mensurados, em casa-de-vegetação. Em condições de campo os fungicidas não apresentaram efeito sobre o controle dos patógenos e sobre o sinergismo da atuação dos dois patógenos inoculados no solo, na dose recomendada comercialmente.

Há necessidade de se pesquisar o uso de fungicida aplicado a superfície do solo para promover um melhor controle dos patógenos principalmente da Rhizoctonia. Acredita-se, no caso da alfafa, que grande parte do fungicida utilizado no tratamento de 
semente seja colocado fora do solo no momento da emergência quando a testa da semente é elevada para superfície.

Existe um resultado interativo entre o uso de fungicidas no tratamento de semente ou em superficie e a estirpe de Rhizobium meliloti utilizada. Esse trabalho mostra que a estirpe SEMIA 116 apresentou os melhores resultados na presença de fungicidas, expressos principalmente pelos maiores valores de porcentagem de Nitrogênio e peso-seco da parte-aérea. A estirpe SEMIA 135 apresentou-se sensível ao tratamento de solo com o fungicida Iprodione.

As taxas de semeadura acima de $10 \mathrm{Kg} /$ ha são desnecessárias quando se avalia o stand de Alfafa para produção. A presença dos patógenos Rhizoctonia e Fusarium provoca drástica redução na \% de sobrevivência das plântulas chegando a permitir somente cerca de $2 \%$ de sobrevivência. 


\section{REFERÊNCIAS BIBLIOGRÁFICAS}

BACKMAN, P.A. Effects of seed-treatment fungicides on Rhizobium inoculants. Highlights of Agricultural Research, Auburn, 25 (5):14, 1978.

BRASIL, Ministério de Agricultura. Secretaria Nacional de Defesa Agropecuária. Regras para análise de semente, Brasília, 1992, 365 p.

CECATTO, L.C.S.B. Seleção e comportamento de Bradyrhizobium japonicum para produção de incoculante comercial. Piracicaba, 1982, 78p. (Mestrado - Centro de Energia Nuclear na Agricultura/USP).

Compêndio de Defensivos Agricolas - Guia Prático de Produtos Fitossanitários para Uso Agrícola. São Paulo, 1990, 478 p.

COWETT, E. R. \& SPRAGUE, M. A. Factors affecting tillering in alfalfa. Agronomy Journal, 54:294-297, 1962.

EICHELBERGER, L. Cultura da alfafa, $31 \mathrm{p}$.

ERWIN, D.C. Diseases caused by Fungi Phytophthora root-rot. In: STUTEVILLE, D.L. \& ERWIN, D.C. Compendium of alfalfa diseases. 2 ed. St. Paul, APS PRESS, 1990. p. 37-8. 
FORNEY, R.D.; CHESTER, L.F.; WOLF, D.D Weed suppression in no till alfalfa (Medicago sativa) by prior cropping of summer-annual forage grasses. Weed Science, Champaign, 33 (4):490-497, July 1985.

GOMES, F.P. Análise de grupos de experimentos In: Curso de estatística experimental, 12. ed. São Paulo, Livraria Nobel. 1987. p. 126-50.

GRAU, C.R. Pythium seed rot, damping-off, and root-rot. In: STUTEVILLE, D.L. \& ERWIN, D.C. Compendium of Alfalfa Diseases. 2. ed. St. Paul, APS PRESS, 1990. p. 11-2.

GUPTA, S.B.; RAWAT, A.K.; KHARE, A.K. Effect of pre and post inoculation seed treatment with fungicides on nodulation and grain yield soybean. Legume Research, Harya, 11(4):167-72, 1988.

HANCOCK, J.G. Seedling diseases of alfalfa in California. Plant Disease, St. Paul, 67:1203-8, Nov., 1983.

HANCOCK, J.G. Fungal rootlet colonization and forage yields of alfalfa in fungicidetreated field plots. Plant Disease, St. Paul, 77 (6):601-8, Jun., 1983.

HAWTHORNE, B.T. Some factors associated with poor emergence and growth of Lucerne seedlings in soils from "RUNOUT" Lucerne Crops. Proceedings Agronomy Society of New Zeland, 17:29-33, 1987.

HONDA,C.S. \&HONDA, A.M. Cultura da Alfafa. IARA Artes Gráficas Ltda, Cambará, 1990. $245 \mathrm{p}$. 
ISOI, T. \& YOSHIDA, S. Effect of Thiram (Tetramethyl-Thiuram-Disulphide) application on nodulation in soybean and Kidney bean plants: observation using the root-box-culture technique. Soil Science and Plant Nutrition, Tokyo, 34(4):633-7, 1988.

KEPLIN, L.A.S. \& SANTOS, I.R. dos. Princípios e práticas para o estabelecimento e manejo da cultura de alfalfa. Suplemento Jornal da Dirat, Carambeí, 84:17-23, 1991.

KEUREN, R.W. van. Alfafa establishment and seeding rata studies. Ohio Report, Ohio, p. 52-4, Mar./Apr., 1973.

MARINGONI, A.C.; TOFOLI, J.G.; FREGONESE, L.H. Sensibilidade in vitro e in vivo de Rhizoctonia solani Kuhn do feijoeiro a fungicidas. Summa Phytopathologica, Jaguariúna, 17:22, 1991. (resumo).

MARKS, G.C. \& MITCHEL, A. Detection, isolation and pathogenicity of Phytophthora megasperma from soils and estimation of inoculum levels. Phytopathology, St. Paul, 60:1687-90, 1970.

MÅTENSSON, A.M. Effects of Agrochemicals and heavy metals on fast-growing Rhizobia and their symbiosis with small-seeded legumes. Soil Biology and Biochemistry, Oxiford, 24(5):435-45, 1992.

MONTEIRO, R.T.R.; BARAIBAR, A; TSAI, S.M. Sobrevivência de Rhizobium leguminosarium bv. phaseoli em sementes tratadas com fungicidas. Revista Microbiológica, São Paulo, 21(1):55-9, 1990. 
ODEYEMI, O. \& ALEXANDER, M. Use of fungicide-resistant Rhizobia for legume inoculation. Soil Biology and Biochemistry, Oxford, 9:247-51, 1977.

OLIVEIRA, J.A. Efeito do tratamento com fungicida em sementes de plântulas de pepino (Cucumus sativus L.) e pimentão (Capsicum annuum L.). Lavras, 1991. 11lp. (Mestrado - Escola Superior de Agricultura de Lavras).

OSTIZ, S.B. de; MUSUMECI, M.R.; TSAI, S.M. Efeito de alguns agrotóxicos na sobrevivência e na atividade respiratória de Rhizobium leguminosarum e Bradyrhizobium japonicum. Pesquisa Agropecuária Brasileira. Brasília, 24(6):663-7, Jun., 1989.

PURVES, R.G.; WYAN-WILLIAMS, R.B. e LEOD. M.C. Lucerne cultivar establishment and performance when sown after lucerne. Proceedings Agronomy Society of New Zeland, 17:25-28, 1987.

RENNIE, R.J.; HOWARD, R.J.; SWANSON, T.A.; FLORES, G.H.A. The effect of seed-applied pesticides on growth and $\mathrm{N}_{2}$ fixation in Pea, Lentil and Fababean. Canadian Journal of Plant Science, Ottawa, 65:230-8, Jan. 1985.

RODHES, L.H. \& MYRES, D.K. Effect of seed treatment with metalaxyl or pyroxyfur on damping-off alfalfa caused by Phytophthora megasperma f. sp. medicaginis. Crop Protection, Oxford, 8:369-72, Out. 1989.

RUSH, C.M \& WINTER, S.R. Influence of Previous Crops on Rhizoctonia Root and Crown Rot of Sugar Beet. Plant Disease, St. Paul, 74:421-5, Jun., 1990. 
SAS/Inc. User's guide; the GLM Procedure Output 20.16. Repeated Measurer Analysis of Variance: Proc GLM.549-640, 1987.

STREETER, J. Inhibition of legume nodule formation and $\mathrm{N}_{2}$ fixation by nitrate CRC Critical Reviews in Plant Science, Boca Raton, 7(1):1-23, 1988.

TESAR, M.B. \& JACKCOBS, J.A. Establishing. In: HANSON, C.H. ed. Alfafa science and technology, Madison, American Society Agronomy, 1972. p.415-35.

TESAR, M.B. \& MARBLE, V.L. Alfalfa establishment, In: HANSON, A.A.; BARNES, O.K.; HILL Jr., R.R., ed. Alfalfa and alfalfa improvement, Madison, American Society of Agronomy, Crop Science Society of America, Soil Science of America, 1988.p.303-32

TRIPLETT Jr., C.B.; KEUREN, R.W. van; WALKER, J.D. Influence of 2,4 D, pronamide, and simazine on dry-matter production and botanical composition of an Alfalfa-grass sward. Crop Science, Madson, 17:62-5, Jan./Feb. 1977.

TRUCHET, G.L. \& DAZZO, F.B. Morphogenesis of lucene root nodules incited by Rhyzobium meliloti in the presence of combined nigrogen. Planta, Würzburg, $154: 352-60,1982$.

TSAO, P.H. Selective media for isolation of pathogenic Fungi. Annual Review of Phytopathology; Palo Alto, 8:177-86, 1970.

TU, C.M. Effect of fungicidal seed treatments on alfalfa growth and nodulation by Rhizobium meliloti. Chemosphere, London, 10:127-34, 1981. 
TYLER, L.J.; MURPHY, R.P.; MAC DONALD, H.A. Effect of seed treatment on seedling stands and on hay yields of forage legumes and grasses. Phytopathology, St. Paul, 46:37-44, Jan. 1956. 